\title{
The ER Glycoprotein Quality Control System
}

Selma Dejgaard ${ }^{1}$, Johan Nicolay ${ }^{1}$, Maryam Taheri ${ }^{1}$, David Y. Thomas ${ }^{2}$ and John J.M. Bergeron ${ }^{1 *}$

${ }^{1}$ Department of Anatomy and Cell Biology, McGill University, 3640 University Street, Montreal, Quebec, H3A 2B2, Canada

${ }^{2}$ Department of Biochemistry, McGill University, Montreal, Quebec, Canada

\begin{abstract}
The endoplasmic reticulum (ER) is the major site for folding and sorting of newly synthesized secretory cargo proteins. One central regulator of this process is the quality control machinery, which retains and ultimately disposes of misfolded secretory proteins before they can exit the ER. The ER quality control process is highly effective and mutations in cargo molecules are linked to a variety of diseases. In mammalian cells, a large number of secretory proteins, whether membrane bound or soluble, are asparagine (N)-glycosylated. Recent attention has focused on a sugar transferase, UDP-Glucose: glycoprotein glucosyl transferase (UGGT), which is now recognized as a constituent of the ER quality control machinery. UGGT is capable of sensing the folding state of glycoproteins and attaches a single glucose residue to the $\mathrm{Man}_{9} \mathrm{GICNAC}_{2}$ glycan of incompletely folded or misfolded glycoproteins. This enables misfolded glycoproteins to rebind calnexin and reenter productive folding cycles. Prolonging the time of glucose addition on misfolded glycoproteins ultimately results in either the proper folding of the glycoprotein or its presentation to an ER associated degradation machinery.
\end{abstract}

\section{Introduction}

UDP-Glucose: glycoprotein glucosyl transferase (UGGT) is a lumenal endoplasmic reticulum (ER) enzyme that plays a sensor role in a molecular machine known as the calnexin/calreticulin (CNX/CRT) cycle (Figure 1) (for recent reviews, Helenius et al., 1997; Zapun et al., 1999; Jakob et al., 2001b; Parodi, 2000). The principal constituents of this molecular machine are two lectins, the ER transmembrane protein calnexin (Bergeron et al., 1994) and its soluble lumenal paralogue calreticulin (Michalak et al., 1999), and the enzymes glucosidase II (Brada and Dubach, 1984; Trombetta et al., 1996) and UGGT (Sousa et al., 1992; Trombetta and Parodi, 1992). In the ER lumen, the asparagine $(\mathrm{N})$-linked oligosaccharides of newly synthesized glycoproteins undergo trimming by glucosidases (Brada and Dubach, 1984; Hettkamp et al., 1984; Trombetta et al., 1996) immediately after transfer of

*For correspondence. Email john.bergeron@mcgill.ca. the core glycan, $\mathrm{Glc}_{3} \mathrm{Man}_{9} \mathrm{GlcNAc}_{2}$, to the asparagine residue within the consensus sequence Asn-X-Ser/Thr (where $X$ is any amino acid except proline) of the growing polypeptide chain (Kornfeld and Kornfeld, 1985; Burda and Aebi, 1999). Membrane bound glucosidase I (Hettkamp et al., 1984) and the soluble glucosidase II (Brada and Dubach, 1984; Trombetta et al., 1996) remove the alpha 1,2-glucose and alpha 1,3-glucose residues, respectively. The sequential action of glucosidase I and II generates glycoproteins having the monoglucosylated oligosaccharide $\mathrm{Glc}_{1} \mathrm{Man}_{9} \mathrm{GlcNAc}_{2}$, which is a substrate for binding to CNX/CRT (Hammond et al., 1994). Calnexin and calreticulin also interact with the PDI orthologue ERp57. This interaction assists in disulfide interchange of calnexin associated glycoproteins (Oliver et al., 1997; Zapun et al., 1998; Molinari and Helenius, 1999). Glucosidase II, apparently irrespective of the protein conformation, trims the last glucose residue on the oligosaccharide side chain of glycoproteins (Pelletier et al., 2000; Schrag et al., 2001; Zapun et al., 1997; Rodan, 1996), thus eliminating their recognition by calnexin or calreticulin. Conversely, UGGT can add back a single glucose unit from UDP-Glc in an $\alpha(1-3)$ bond to the terminal mannose of the $\alpha(1-3)-\alpha(1-2)$ branch of $\mathrm{Man}_{7-9} \mathrm{GlcNAc}_{2}$, restoring the monoglucosylated oligosaccharide molecule as a substrate for CNX/CRT interaction (Parodi, 2000; Rodan et al., 1996; Sousa and Parodi, 1995; Trombetta and Parodi, 1992; Wada et al., 1997; Zapun et al., 1997). The sum of the action of the three components is to act as a molecular chaperone to detain incompletely folded proteins in the ER. That UGGT was a component of such a molecular chaperone system became apparent following the discovery by Parodi that the enzyme targets denatured substrates which may be taken as surrogates for incorrectly folded proteins (Parodi, 2000). UGGT can sense and select incompletely folded glycoproteins for a further cycle of folding (Parodi, 2000; Zapun et al., 1997; Rodan et al., 1996; Sousa and Parodi, 1995; Wada et al., 1997), as well as discriminate among different nonnative conformers (Parodi, 2000; Sousa et al., 1992; Rodan et al., 1996; Sousa and Parodi, 1995). If the protein is folded, it is not reglucosylated and escapes this cycle, thereby releasing the glycoprotein to exit from the ER, after ER mannosidase processing. If secretory proteins fail to fold correctly in the $\mathrm{ER}$, they are targeted to the ER-associated degradation (ERAD) machinery (Fewell et al., 2001; Hampton, 2002; Jarosch et al., 2002), also after ER mannosidase processing (Weng and Spiro, 1993; Jelinek-Kelly and Herscovics, 1988) and the downstream involvement of a novel lectin (Mn11p/ Htm1p / EDEM; Hosokawa et al., 2001; Jakob et al., 2001a; Nakatsukasa et al., 2001; Figure 1). Collectively, these mechanisms have been referred to as the ER quality control of protein folding and degradation (for recent reviews, Helenius et al., 1997; Jakob et al., 2001a; Parodi, 2000; Zapun et al., 1999). UGGT is the sole known constituent of the calnexin cycle to read the polypeptide code for folding and thereby distinguish 
between productively folded and misfolded glycoproteins (Zapun et al., 1999). However, the molecular mechanisms by which this process happens remain unclear. The identification of UGGT isoforms without glucosyl transferase activity further adds to the complexity of the sensors of glycoprotein folding. Understanding the mechanism of glycoprotein recognition of by the UGGT family may be of relevance to protein trafficking diseases.

\section{UDP-Glucose:glycoprotein glucosyl transferase}

The enzyme activities have been partially characterized from Trypanosoma cruzi (Parodi and Cazzulo, 1982; Parodi, 2000), Schizosaccharomyces pombe (Fernandez et al., 1994), Drosophila melanogaster (Parker et al., 1995) and rat liver (Trombetta and Parodi, 1992). UGGT is ubiquitously expressed in the ER of most eukaryotic species (Trombetta et al., 1989) and has been sequenced from different sources (Arnold et al., 2000; Fernandez et al., 1994; Parker et al., 1995; Tessier et al., 2000). Recombinant rat (Tessier et al., 2000) and human (Arnold et al., 2000) UGGTs have been expressed in insect and mammalian cells, respectively. The rat enzyme is a large, soluble glycoprotein of $170 \mathrm{kD}$ with an ER localization signal (variants of the His-Asp-Glu-Leu (HDEL) retention signal) at its C-terminus. It is present in the ER lumen (Parodi, 2000; Trombetta and Parodi, 1992) and in pre-Golgi intermediates (Zuber et al., 2001). The optimal enzyme activity is at neutral $\mathrm{pH}$ and is $\mathrm{Ca}^{2+}$ or $\mathrm{Mn}^{2+}$-dependent (for a recent review, Parodi, 2000).

Classification of known glycosyltransferases has been based on sequence homologies (Breton et al., 1998; Campbell et al., 1997). Recently, the D. melanogaster and $S$. pombe UGGT homologues (which are grouped with $C$. elegans 2, and the sequence related killer toxin-resistance protein Kre5p from S. cerevisiae (Meaden et al., 1990) into family 24 in ref. Campbell et al., 1997) were placed in the galactosyltransferase Family B by their structural homology to bacterial proteins (the glycosyltransferases of family 8 in ref. Campbell et al., 1997) involved in lipopolysaccharide core biosynthesis (Breton et al., 1998). The full-length sequence alignments of known and putative UGGTs reveals a highly conserved 300 amino acid sequence $(30 \%$ of the molecule, $60-70 \%$ identity) in the $\mathrm{C}$-terminal domain (Breton et al., 1998; Tessier et al., 2000) (Figure 2). Limited but significant similarity exists between this highly conserved domain and several bacterial transferases that utilize UDP-Glc or UDP-Gal as a substrate donor (Breton et al., 1998). Therefore, the C-terminal domain of UGGT is responsible for recognition of the donor nucleotide-sugar and likely contains the catalytic domain: In this C-terminal region, two conserved motifs have been detected. DxD ( $\mathrm{x}$ is any amino acid) is the most conserved motif observed in the galactosyltransferase Family B (Figure 2) which probably provides the binding site for the UDP-sugar (Tessier et al., 2000; Arnold et al., 2000) and DQDxxN which is probably involved in recognition of the $\mathrm{N}$ acetylglucosamine residue linked to the Asn residue of the glycoprotein substrate to which the sugar is transferred (Tessier et al., 2000; Arnold et al., 2000). The N-terminal domains of UGGTs reveal a lower degree of sequence similarity and have been proposed to be responsible for the recognition of protein conformations (Parodi, 2000; Guerin and Parodi, 2003).

\section{Substrate recognition by UGGT}

UGGT can recognize both the glycan and the protein moiety of incompletely folded glycoproteins, preferentially in molten globule-like conformers (Parodi, 2000; Caramelo et al., 2003; Sousa et al., 1992; Sousa and Parodi, 1995). The innermost GlcNAc unit of the glycoprotein's oligosaccharide is proposed to be required for UGGT recognition. Denatured nonglucosylated proteins do not affect UGGT activity, whereas denatured glycoproteins from which oligosaccharides have been removed by endo- $\beta-\mathrm{N}$ acetylglucosaminidase $\mathrm{H}$ (Endo $\mathrm{H}$ ) treatment (i.e. leaving a single GlcNAc-Asn) are efficient inhibitors of UGGT activity (Sousa and Parodi, 1995), but Endo H digested native glycoproteins with a remaining GIcNAc residue are not inhibitors of UGGT activity (Parodi, 2000; Sousa and Parodi, 1995). Thus, this innermost GlcNAc moiety must be covalently linked to a denatured glycoprotein. UGGT then recognize the covalently-linked $\operatorname{Man}_{9} \mathrm{GICNAC}_{2}$ denatured protein as substrate (Sousa and Parodi, 1995).

The exposed hydrophobic patches in incompletely folded glycoproteins, that would otherwise be hidden domains in native conformers, are recognized by the enzyme (Sousa et al., 1992; Sousa and Parodi, 1995). This is supported by observations demonstrating that interaction with immobilized hydrophobic stretches, but not with hydrophilic peptides, is inhibited by denatured but not by native glycoproteins (Sousa et al., 1992; Sousa and Parodi, 1995). Consequently, it has been proposed that UGGT senses the exposed hydrophobic residues in a way similar to many classical molecular chaperones (Sousa and Parodi, 1995).

To date, it has been unclear how these exposed hydrophobic stretches influence UGGT's ability to recognize and reglucosylate its substrates. However, hydrophobic residues on substrate glycoproteins may directly and/or with other molecular chaperones (BiP [binding protein, a member of the heat shock protein 70 family]) enhance the preferential selectivity of UGGT for incompletely folded glycoproteins (Caramelo et al., 2003; Taylor et al., 2003). In contrast to previous reports, it has recently been shown that short glycopeptides with different amino acid sequences are recognized by UGGT. Furthermore, hydrophobic residues close to $\mathrm{N}$-linked glycan seem to be the main determinant for recognition by UGGT (Taylor et al., 2003). We speculate that these peptiderecognition elements may be in close proximity to glycans in folding intermediates (Taylor et al., 2003). Although both proteins recognize hydrophobic patches exposed during folding process, UGGT glucosylates glycoproteins preferentially in molten globule-like conformations, whereas $\mathrm{BiP}$ recognizes heptapeptides with large hydrophobic residues (Blond-Elguindi et al., 1993) in an extended structure (Caramelo et al., 2003). It has consequently been speculated that BiP would interact with a relatively extended structure in early stage of glycoprotein folding rather than UGGT. This is consistent with other observations that 


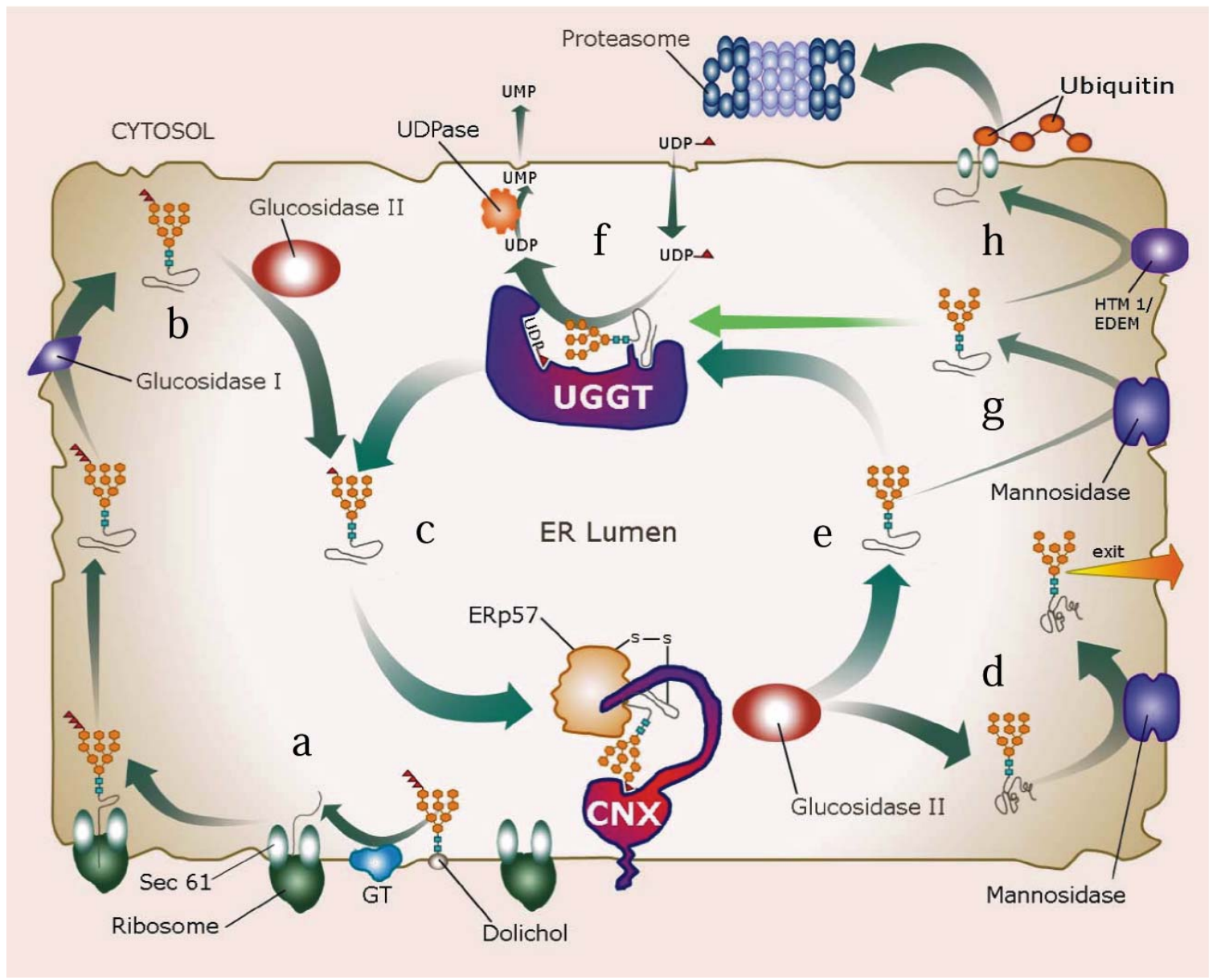

Figure 1. CNX/CRT cycle. In the ER, the action of two enzymes, glucosidase II and UGGT, regulate the release and binding of glycoproteins to CNX/CRT providing a unique quality control mechanism known as the CNX/CRT cycle (Helenius et al., 1997) for glycoprotein folding. (a) The precursor glycan $\left(\mathrm{Glc}_{3} \mathrm{Man}_{5-9} \mathrm{GlcNAc}_{2}\right)$ linked to the lipid molecule, dolichol (Burda and Aebi, 1999), is transferred to the NH2 group on the side chain of asparagine residues positioned in a consensus sequence Asn-X-Ser/Thr (where $X$ is any amino acid except proline) in the growing, nascent polypeptide chain (Kornfeld and Kornfeld, 1985), as soon as it enters the ER lumen via the Sec61p translocon complex (Lodish et al., 1983). The transfer is catalyzed by membrane-bound glycosyl transferases, which recognizes a specific conformation of Asn-X-Ser/Thr sequences (Silberstein and Gilmore, 1996). (b) Glucosidase I and II successively trim two of the glucose residues leaving the $\mathrm{Gl}_{1} \mathrm{Man}_{9} \mathrm{GlcNAc}_{2}$ core oligosaccharide. (c) Calnexin and its lumenal paralogue calreticulin are lectins that specifically bind monoglucosylated oligosaccharides, and present them to the glycoprotein-specific thiol oxidoreductase, ERp57, which also bound to CNX/CRT. If the complete deglucosylation of glycoproteins occurs before the CNX-glycoprotein interaction, the monoglucosylated glycoproteins are also generated by reglucosylation through the action of UGGT. Trimming of the last glucose residue by glucosidase II terminates the calnexin-glycoprotein interaction. If the proteins are correctly folded (d) they proceed further into the secretory pathway, whereas incompletely folded proteins (e) are recognized by UGGT. (f) UGGT reglucosylates incompletely folded proteins by readdition of a single glucose residue from UDP-Glc thereby generating a substrate for the calnexin cycle. UDP-Glc is transported into the ER lumen from the cytosol and is exchanged to uridine monophoshate (UMP) by uridine diphosphatase (UDPase) (Trombetta and Helenius, 1999), and UMP is transported back to cytosol. (g) The CNX/CRT cycle continues until the proteins are correctly folded or directed to ER-associated degradation (ERAD) after trimming by ER $\alpha 1,2$-mannosidases. (h) An enzymatically inactive member of this protein family, ER Degradation Enhancing $\alpha$-Mannosidase-like protein (EDEM) and the yeast homologue Mn11p (mannosidase-like protein) or Htm $1 \mathrm{p}$ (homologous to mannosidase I, shown as HTM 1) may participate as lectins and promote ERAD of incorrectly folded proteins that are then transported to the cytosol via the Sec61p translocon complex where they are proteolytically degraded by the proteasome system, in most cases following polyubiquitination.

UGGT functions at later stages of glycoprotein folding (Parodi, 2000) and efficiently recognizes a variety of partially folded conformers (Trombetta and Helenius, 2000). Indeed, it has been shown that UGGT glucosylates the endogenous trypanosome substrate of UGGT, cruzipain (a lysosomal cysteine proteinase with two or three $\mathrm{N}$-linked oligosaccharides and six or seven disulfide bridges) after it has obtained a tertiary structure that closely resembles the native conformer (Parodi, 2000). Since hydrophobic patches on glycoprotein substrates are introduced into a cleft in the bacterial homolog of $\mathrm{BiP}$ (DNaK) structure, it is then suggested that UGGT might require a larger surface interaction with its substrate glycoproteins for reglucosylation than $\mathrm{BiP}$ (Caramelo et al., 2003).

In addition, in glycoproteins with multiple independently folding domains, UGGT recognizes folding defects at the level of individual domains and only reglucosylates glycans in the misfolded domains (Ritter and Helenius, 2000). This may allow the CNX/CRT cycle to interact with only unfolded parts of the glycoproteins depending on distribution of 


$\begin{array}{lr}\text { H. sapiens1 } & 1251 \\ \text { H. sapiens2 } & 1227 \\ \text { R. norvegicus } & 1227 \\ \text { D. melanogaster } 1234 \\ \text { C. elegans1 } & 1198 \\ \text { C.elegans2 } & 1087 \\ \text { A. thaliana } & 1338 \\ \text { S. pombe } & 1155 \\ \text { S. cerevisiae } & 1093\end{array}$

$\begin{array}{lr}\text { H. sapiens1 } & 1314 \\ \text { H. sapiens2 } & 1289 \\ \text { R. norvegicus } & 1290 \\ \text { D. melanogaster } 1298 \\ \text { C. elegans1 } & 1260 \\ \text { C. elegans2 } & 1150 \\ \text { A.thaliana } & 1402 \\ \text { S. pombe } & 1215 \\ \text { S. cerevisiae } & 1159\end{array}$

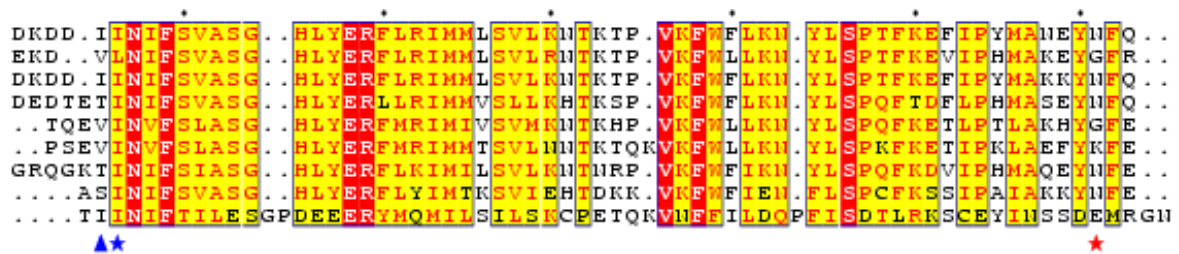

$\Delta \star$

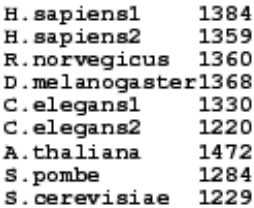

S. cerevisiae 1229
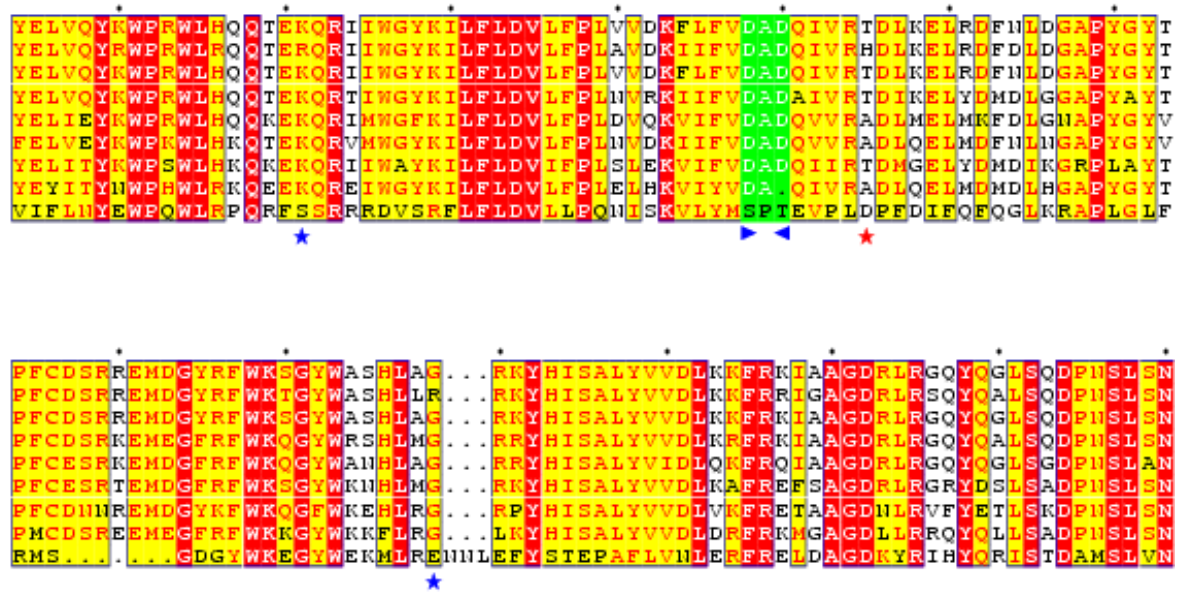

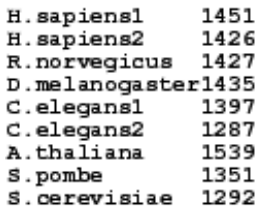

S. cerevisiae 1292

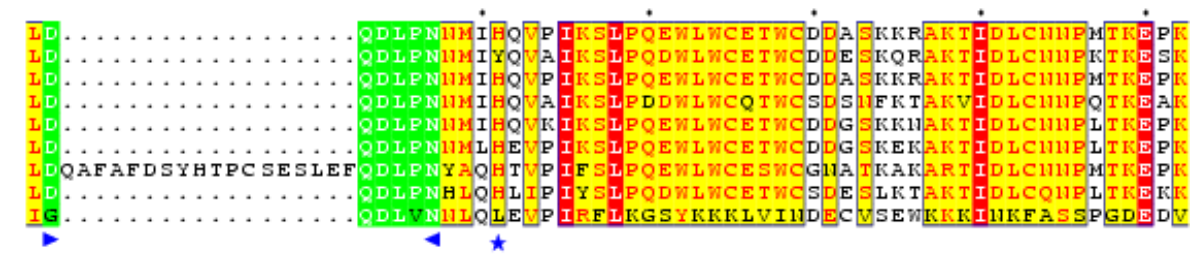

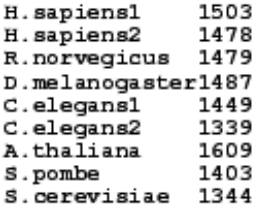

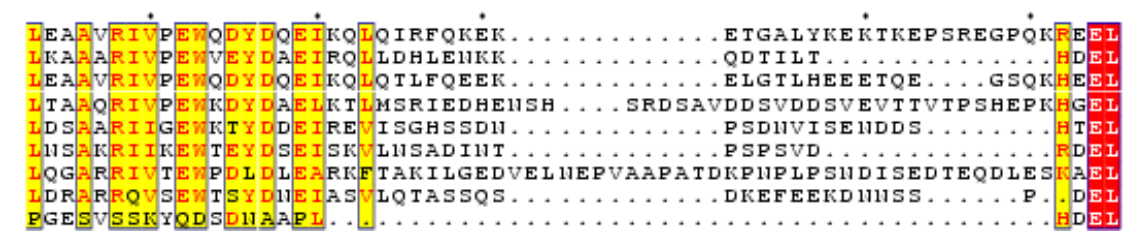

Figure 2. Alignment of protein sequences from UGGTs in the C-terminal region of the protein. Although the cDNA sequence encoding UGGT protein from different sources shows a high degree of sequence homology extending over the entire sequence of the protein, it is particularly high in the C-terminal region of the protein. The color key is: red box, white letter for strict identity, red character for similarity in a group, blue frame filled in yellow shows similarity across groups. The boundary of the proposed catalytic domain (is shown with $\Delta$ ) identified for $H$. sapiens 1 (Arnold et al., 2000) is about 300 residues from the Cterminus. Highly conserved catalytic domain motifs (in $H$. sapiens UGGT 1 sequence, residues 1357-1360 and $1452-1457$ respectively) in all UGGTs except S. cerevisiae Kre5p are shown with $\downarrow$, in green box, white letter. Conserved residues in all homologues but both H. sapiens UGGT 2 (Arnold et al., 2000) and S. cerevisiae (except the first residue) are denoted with blue $\star$ under the sequences (in hUGGT1 sequence, I 1256, K 1331, G 1409, H 1461). Other candidate residues that differ from the known active UGGTs $(H$. sapiens1, $R$. norvegicus, $D$. melanogaster, $S$. pombe UGGT proteins) for the inactive UGGT sequences ( $H$. sapiens2 and $S$. cerevisiae proteins) are donated with red $\star$ under the sequences (in hUGGT1 sequence, N 1311, T 1365).

glycosylation sites. Such recognition may be important for large molecules that have multiple independently folding domains (Ritter and Helenius, 2000). This then raises the more fundamental question that concerns the evolution of $\mathrm{N}$-linked sites of glycosylation in mammalian glycoproteins. Have these sites evolved to identify locations in a polypeptide that are critical to UGGT-mediated presentation to the CNX/CRT cycle? The degree of conservation of most $\mathrm{N}$-linked glycans in glycoproteins is high (Dwek et al., 2002; Rudd et al., 2001a; Rudd et al., 2001b; Rudd et al., 2001c). For viral envelope glycoproteins, all of which use the CNX/ CRT cycle for productive folding, these conserved sites of $\mathrm{N}$-linked glycosylation have evolved as essential for viral biogenesis (Rudd et al., 2001a; Rudd et al., 2001b; Rudd 
et al., 2001c). Hence, evolution may have selected the polypeptide domains within which a subset of $\mathrm{N}$-glycans is found for presentation to UGGT as part of the protein folding code required for correct glycoprotein folding in the calnexin cycle.

\section{UGGT in quality control, degradation and sorting}

\section{Quality control}

Calnexin and/or calreticulin bind transiently to almost all soluble and membrane bound glycoproteins during folding or oligomeric assembly of the glycoproteins in the ER (Hammond et al., 1994; Helenius et al., 1997; Ou et al., 1993). Trypanosomatid protozoa cells express calreticulin but lack calnexin and in these cells $\mathrm{Man}_{6-7} \mathrm{GlcNAc}_{2}$, or $\mathrm{Man}_{9} \mathrm{GlcNAc}_{2}$ is transferred to the nascent polypeptide chain by oligosaccharyltransferase. Thus, in these cells creation of a Glc $\mathrm{Man}_{9} \mathrm{GlcNAc}_{2}$ glycoprotein that can bind calreticulin is only via the action of UGGT (Labriola et al., 1999; Parodi and Cazzulo, 1982). In contrast, all mammalian species transfer triglucosylated (i.e. $\mathrm{GlC}_{3} \mathrm{Man}_{9} \mathrm{GlcNAc}_{2}$ ) structures to nascent polypeptide chains and also possess UGGT and thus there is a dual route of presentation to CNX/CRT either via the sequential activity of glucosidase I and II or by reglucosylation by UGGT (Parodi, 2000). This difference between cells from various trypanosome species and mammalian cells may predict regulation of entry into the CNX/CRT cycle at the level of substrates presented to the oligosaccharyltransferase. Such a regulation of dolicholbased intermediates in the biosynthetic pathway of $\mathrm{Glc}_{3} \mathrm{Man}_{9} \mathrm{GlcNAc}_{2}$ has recently been observed in normal primary cells undergoing a stress response (Doerrler and Lehrman, 1999), although its precise physiological significance remains to be established. Misfolded glycoproteins enter a cycle of binding to and release from CNX/CRT mediated by the sequential actions of UGGT and glucosidase II as originally proposed by Hammond et al (Hammond et al., 1994; Parodi, 2000; Trombetta and Parodi, 1992). This ultimately results in either the proper folding of the glycoprotein or its disposal (Fewell et al., 2001; Helenius et al., 1997; Jarosch et al., 2002; Ou et al., 1993; Parodi, 2000). In this context, the CNX/CRT cycle acts as a kinetic trap, retaining conformers that are not correctly folded, and allowing only the native conformers to move further along the secretory pathway (Labriola et al., 1999; Le et al., 1994; Ou et al., 1993; Pind et al., 1994). In support of this suggestion is the observation that the ER retention half-times of glycoproteins correlate with half times of their secretion, as well as their rank order of calnexin binding (Lodish et al., 1983; Ou et al., 1993). The demonstration in mammalian cells that UGGT activity can transform intermolecular oxidized aggregates of misfolded transferrin, a secretory glycoprotein of the liver, into monomeric productively folded transferrin is good evidence that reglucosylation by UGGT has a central role in quality control in vivo (Wada et al., 1997).

Most of the glycoproteins are reglucosylated during their maturation in the ER, including influenza HA (Hebert et al., 1995), vesicular stomatitis virus G protein (Suh et al., 1989), transferrin (Wada et al., 1997), T cell receptor subunits (Van Leeuwen and Kearse, 1997) and cruzipain (Labriola et al., 1999). Reglucosylation may mediate the selection of the chaperones in vivo (Trombetta and Helenius, 2000). For example, vesicular somatitis virus glycoprotein binds to BiP during its early stage of folding, and later it is possible that reglucosylation mediates its binding to calnexin (Hammond et al., 1994). Recently, it has been speculated (Caramelo et al., 2003) that the preferential recognition of the glycoprotein substrates by UGGT and BiP might provide a molecular rationale for sequential interaction between $\mathrm{BiP}$ and CNX/CRT with folding glycoproteins (Hammond et al., 1994; Kim and Arvan, 1995; Molinari and Helenius, 2000).

In vitro, both UGGT and glucosidase II showed the highest relative rate of glucosylation/deglucosylation for glycoproteins containing $\mathrm{Man}_{9} \mathrm{GlcNAc}_{2}$ (Grinna and Robbins, 1980; Sousa et al., 1992). Relative glucosylation rates by UGGT were respectively 100, 50, and 15 for $\mathrm{Man}_{9}$, $\mathrm{Man}_{8}$, and $\mathrm{Man}_{7}$ (Parodi, 2000; Sousa and Parodi, 1995). Similar to UGGT, glucosidase II also revealed reduced deglucosylation rates for substrate glycoproteins upon the removal of mannose residues (Grinna and Robbins, 1980). Hence these data led to a proposal that quality control in the ER is also regulated by demannosylation (Cabral et al., 2001).

\section{ER-associated degradation}

ER-associated degradation has a central clearance function in the cell (Fewell et al., 2001; Hampton, 2002; Jarosch et al., 2002). In this pathway, terminally misfolded proteins are subjected to trimming by ER $\alpha 1,2-$ mannosidase(s) (Jelinek-Kelly and Herscovics, 1988; Weng and Spiro, 1993) and are transported to the cytosol via the Sec61p translocon complex (Pilon et al., 1997; Wiertz et al., 1996). They are then polyubiquitinated and proteolytically degraded by the cytosolic $26 \mathrm{~S}$ proteasome. Ubiquitination appears to be required for both retrotranslocation to the cytosol and proteasomal degradation (see in reviews, Fewell et al., 2001; Hampton, 2002; Jarosch et al., 2002).

The relatively slow-acting ER $\alpha 1,2$-mannosidase is responsible for mannose trimming of the oligosaccharide side chain, irrespective of the protein conformation, generating primarily $\mathrm{Man}_{8} \mathrm{GlcNAc}_{2}$ isomer $\mathrm{B}$ in mammalian cells (Weng and Spiro, 1993), and only Man $_{8}$ GlcNAC $_{2}$ isomer B in S. cerevisiae (Jelinek-Kelly and Herscovics, 1988). The resulting $\mathrm{Man}_{8}$ structure can be recognized by an enzymatically inactive mannosidase I, called Mn11p (mannosidase-like protein; Nakatsukasa et al., 2001) or Htm1p (homologous to mannosidase I; Jakob et al., 2001a) in yeast and EDEM (ER Degradation Enhancing $\alpha$ Mannosidase-like protein; Hosokawa et al., 2001) in mammalian cells. EDEM seems to be up-regulated by the unfolded protein response through the XBP1 pathway (Yoshida et al., 2003) and to target the misfolded protein for retrotranslocation and degradation by promoting release from the calnexin (Molinari et al., 2003; Oda et al., 2003). Calnexin, BiP and PDI have also been proposed to work in the recognition phase of misfolded glycoproteins for subsequent retrotranslocation and degradation (Molinari et al., 2002). Other factors may participate in the targeting 


Disease Protein Glycoprotein CNX/CRT Assoc.

I: Loss of coupling to ER export leading to degradation

Cystic fibrosis (Pind et al., 1994)

Hereditary emphysema (Le et al., 1994; Spiro et al., 1996)

Hereditary hemochromatosis (Kühn, 1999)

Protein C deficiency (Tokunaga et al., 2000)

Type 1 hereditary angioedema (Verpy et al., 1993)

Tay-Sachs (Kaback and Desnick, 2001)

Congenital sucrase-isomaltase deficiency (Naim et al., 1988)

Crigler-Najjar type II (Sampietro and Iolascon, 1999)

Polyendocrinopathy/Hyperinsulemia (Reznik and Fricker, 2001)

Diabetes mellitus (Bass et al., 1998)

Laron syndrome (Amselem et al., 1991)

Hereditary myleoperoxidase (Nauseef, 1999; Nauseef et al., 1998)

Primary hypoparathyroidism (Garfield and Karaplis, 2001)

Oculocutaneous albinism (Halaban et al., 1997; Halaban et al., 2002;

Vinayagamoorthy and Rajakumar, 1996)

Fabry disease (Ishii et al., 2000)

Congenital long QT syndrome (Deutsch, 2002; Furutani et al., 1999)

Autosomal dominant retinitis pigmentosa (Frederick et al., 2001;

Saliba et al., 2002; Illing et al., 2002)

\section{Lipid processing deficiencies}

Familial hypercholesterolemia (Jorgensen et al., 2000)

Type 1 chylomicronemia (Ben-Zeev et al., 2002)

Abetalipoproteinemia (Kim and Arvan, 1998)

Low plasma lipoprotein (a) levels (White et al., 1999;

Bonen et al., 1998)

\section{II: Loss of coupling to ER export leading to accumulation in the ER}

Liver diseases/Hereditary emphysema (Qu et al., 1997;

Coakley et al., 2001)

Congenital hypothyroidism/related disorders (Kim and Arvan, 1998)

Thyroglobulin deficiency (Kim and Arvan, 1995)

Thyroid peroxidase deficiency (de Carvalho et al., 1994;

Kim and Arvan, 1995; Fayadat et al., 2000)

Thyroxin-binding globulin deficiency"

(Miura et al., 1994; Refetoff et al., 1996)

Osteogenesis imperfecta (Lamande and Bateman, 1999)

Hereditary hypofibrinogenemia (Roy et al., 1996)

a1- Antichymotrypsin (ACT) deficiency (Callea et al., 1992)

Neurophyseal diabetes insipidus (Morello et al., 2001)

Nephrogenic diabetes insipidus (Tamarappoo et al., 1999)

Charcot-Marie-Tooth disease (Thomas, 1999; Mendell, 1998)

Pelizaeus-Merzbacher disease (Yool et al., 2000; Swanton et al., 2003)

Alzheimer disease (Shastry, 2001)

Straussler-Scheinker syndrome (Rudd et al., 2001b;

Collins et al., 2001)

Hereditary Creutzfeldt-Jacob disease (Rudd et al., 2001b;

Collins et al., 2001)

von Willebrand Disease

Type IIA (Englender et al., 1996; Lyons et al., 1992)

Types I and III (Allen et al., 2001)
Cystic fibrosis transmembrane regulator $\alpha 1-$ Antitrypsin (non PiZ variants) HFE. Loss of binding transferrin receptor Protein C

Complement $\mathrm{C} 1$ inhibitor

$\beta$-Hexosaminidase

Sucrase-isomaltase

Bilirubin-UDP-glucuronosyltransferase 1

Carboxypeptidase E

Insulin receptor

Growth hormone receptor

Myeloperoxidase

Preproparathyroid hormone

Tyrosinase

$\alpha$-D-galactosidase Rhodopsin

Low-density lipoprotein receptor Lipoprotein lipase

Microsomal triglyceride transfer protein Apolipoprotein (a)
Voltage gated potassium channel (HERG)

CNX, Prolonged Assoc. CNX, Prolonged Assoc.

CNX/CRT

CNX

CNX/CRT, Prolonged Assoc.

CNX/CRT, Prolonged Assoc.

CNX, Prolonged Assoc.

CNX transient assoc.

CNX

CNX, Prolonged Assoc.

CNX

CNX/CRT, Prolonged Assoc. CNX/CRT

$\mathrm{CNX}$

$\mathrm{CNX}$

CNX, Prolonged Assoc.

CNX

CNX, Prolonged Assoc.

$\mathrm{CNX}$

$\mathrm{CNX}$

CNX

Prion protein processing defect

VWF

Types I and III associated VWF variant

CNX/CRT, CNX Prolonged Assoc. von Willebrand factor (VWF)

\section{III: Defective transport machiner}

Combined factorsV and VIII deficiency (Nichols et al., 1998)

Ergic-53

SEDL (sedlin)

Viral Infections: Selected examples that are known to be associated with CNX/CRT quality control

AIDS (Land and Braakman, 2001)

Herpes simplex-1 (Yamashita et al., 1996b)

Cytomegalovirus diseases (Yamashita et al., 1996a)

Influenza (Hebert et al., 1996)

Hepatitis B (Prange et al., 1999)

Hepatitis C (Choukhi et al., 1998)

Rubella (Nakhasi et al., 2001)

Measles (Bolt, 2001)

Newcastle disease (McGinnes and Morrison, 1998)

Dengue hemorrhagic fever (Wu et al., 2002)

Japanese encephalitis (Wu et al., 2002)

Uukiniemi virus infenction (Veijola and Pettersson, 1999)

Vesicular somatitis (Cannon et al., 1996)

$160 / 120$

$\mathrm{B}, \mathrm{C}$ and $\mathrm{D}$

B

Haemagglutinin

$\mathrm{M}$

E1 and E2

$\mathrm{E} 1$ and E2

Haemagglutinin/Fusion

Haemagglutinin-neuraminidase

$\mathrm{M}, \mathrm{E}$ and NS1

$\mathrm{M}, \mathrm{E}$ and NSI

$\mathrm{G} 1$ and $\mathrm{G} 2$

G

CNX/CRT

$\mathrm{CNX} / \mathrm{CRT}$

$\mathrm{CNX}$

CNX/CRT

CNX

CNX/CRT

CNX/CRT

CNX/CRT

CNX

$\mathrm{CNX}$

CNX

CNX/CRT

CNX/CRT

Unknown consequences ${ }^{\theta \delta}$

Polycystic liver disease (PCLD, OMIM 174050) ${ }^{\ominus}$ (Drenth et al., 2003) Hepatocystin (also indentified as the

$\beta$-subunit of glucosidase II)

Congenital disorders of N-glycosylation (CDG)-II b

Glucosidase I and II

CNX/CRT cycle constituent

CNX/CRT cycle constituent

* Please see Aridor and Hannan, 2002 for a more complete list of the ER quality control related diseases. ^ placed in the first group in Aridor and Hannan, 2000

${ }^{\theta}$ mutant protein may alter the processing of oligosaccharide chains of various glycoproteins. ${ }^{\delta}$ where the defects are in the trimming and modification of the core oligosaccharide which had already been transferred to the target proteins. 
of misfolded glycoproteins to ERAD (Fewell et al., 2001; Hampton, 2002; Jarosch et al., 2002). For example, the AAA ATPase family members Cdc48 in yeast and p97 in mammals have been shown to be required for the transport of misfolded proteins to the cytosol (Braun et al., 2002; Ye et al., 2001). As well, ubiquitin ligases (the F-box protein Fbx2 of an ubiquitin ligase complex, SCF (Fbx2) [Yoshida et al., 2002], a chaperone-containing ligase, CHIP and E2 [Meacham et al., 2001]) have been shown to participate in ERAD of misfolded proteins, suggesting potential links between ubiquitination, ERAD and quality control of glycoproteins (Fewell et al., 2001; Hampton, 2002; Jarosch et al., 2002). Indeed Qu et al. (Qu, et al., 1996) have proposed that calnexin itself is polyubiquitinated during ERAD, but this observation has not been confirmed.

\section{Retention, retrieval and ER-associated degradation}

In cells which overexpress a temperature sensitive mutant of vesicular somatitis virus $G$ protein, the mutant protein escapes initial ER retention but is retrieved back to the ER bound to the molecular chaperone $\mathrm{BiP}$ from the intermediate compartment (IC) and the cis-Golgi network (Hammond et al., 1994; Hsu et al., 1991). However, the misfolded VSV G mutant protein at the 'exit sites' in the $E R$ is reglucosylated by UGGT and returned to the ER instead of being transported to the Golgi complex (Mezzacasa and Helenius, 2002). Proteins that are localized in the ER possess retention and retrieval signals, including specific C-terminal motifs, such as Lys-Asp-GluLeu (KDEL) for soluble proteins (Pelham, 1996) or dilysine (KKxx) motifs for transmembrane proteins (Fiedler et al., 1996; Itin et al., 1995; Nilsson et al., 1989), that mediate the selective retrograde transport of these proteins from the cis-Golgi back to the ER. Furthermore, it has been shown that membrane bound or soluble forms of misfolded proteins are sorted in the ER, either for retention or retrieval, indicating that different recognition mechanisms may exist to target misfolded proteins for degradation (Vashist et al., 2001). Moreover, it has been reported that a KDEL-receptor mediated mechanism exists for the retrieval of unassembled subunits of the T-cell antigen receptor to the ER for their eventual disposal (Yamamoto et al., 2001).

The presence of glucosidase II, UGGT and calreticulin in pre-Golgi intermediate compartments (Roth et al., 2002; Zuber et al., 2001) suggests that other compartments of the secretory pathway may also have a role in correct folding and quality control (Roth et al., 2002). In addition, endomannosidase, which localizes to the intermediate compartment and has substrate specificity for $\mathrm{Glc}_{1}-\mathrm{Man}_{9} \mathrm{GlcNAc}_{2}$ like glucosidase II, can also act on $\mathrm{Glc}_{3} \mathrm{Man}_{9} \mathrm{GlcNAc}_{2}$ unlike glucosidase II, thus providing an alternative glucosidase II independent pathway (Zuber et al., 2000). However, in contrast to glucosidase II, endomannosidase can also remove the $\mathrm{Glc}_{1}$ Man residues from monoglucosylated oligosaccharides with trimmed mannose chains (for example, Glc Man $_{5-8} \mathrm{GICNAc}_{2}$-structures), suggesting a role for this enzyme in quality control (Roth et al., 2002; Spiro et al., 1996). It is proposed that misfolded $\mathrm{Man}_{8}$-glycoproteins may be released from calreticulin in the intermediate compartment by the action of endomannosidase before their degradation (Zuber et al.,
2000). It has been speculated that the excessive removal of mannose residues may prevent UGGT-mediated reglucosylation of the misfolded glycoproteins thus diverting misfolded proteins away from CNX/CRT and leading to their degradation (Cabral et al., 2001).

\section{The enzymatically "active" and "silent" UGGTs}

Recently, UGGT was also identified as a part of the heavy chain-BiP complex including molecular chaperones and folding enzymes BiP, Glucose-regulated protein (GRP)94 (Endoplasmin), GRP170 (an ER heat shock protein 70 family member), an ER Hsp40 cochaperone (ERdj3), and several PDI family members (PDI, ERp72, , CaBP1), cyclophilin B (an ER immunophilin protein) and the SDF2L1 (an ER stress inducible protein; Meunier et al., 2002). The existence of such a network(s) (Kim and Arvan, 1995; Kuznetsov et al, 1994; Kuznetsov et al, 1997; Tatu and Helenius, 1997) led to a proposal that the ER is organized into different networks containing distinct pool of the ER chaperones (Meunier et al., 2002). This might also explain the retention of some molecular chaperone without KDEL sequences in the ER (see in ref. Meunier et al., 2002). Such a complex may also explain the sequential/ simultaneous interactions of the molecular chaperones with misfolded proteins (as mentioned above) (Hammond et al., 1994). Furthermore, these data suggest that UGGT may well be a part of dynamic molecular chaperone complex, which may also determine the sorting and retrieval of secretory proteins. Such a dynamic network(s) of chaperones could prevent the forward movement of misfolded proteins by their retention (see in ref. Hendershot, 2000). This finding does not rule out the possibility that there are other pools of UGGT not present in the complex (Meunier et al., 2002).

UGGT has also been shown to associate with a misfolded variant of $\alpha 1$-antitrypsin (non PiZ; Choudhury et al., 1997), ER resident enzymes such as the folding enzyme protein disulfide isomerase (PDI), the chaperone $\mathrm{BiP}$, and carboxylesterase (a specific quality control factor which limits ER export of C-reactive protein; Amouzadeh et al., 1997). The enzyme has also been observed in a complex with the selenoprotein, Sep15 (Korotkov et al., 2001), which is suggested to play a role in cancer etiology (see in ref. (Korotkov et al., 2001). It is speculated that Sep15 may play a role in redox reactions in the complex, which would then have an affect on CNX/CRT-mediated folding. However, UGGT is detected in both selenoprotein-bound and selenoprotein-free forms (Korotkov et al., 2001). The physiological significance of UGGT in a complex with selenoproteins and/or other proteins (Amouzadeh et al., 1997; Choudhury et al., 1997; Korotkov et al., 2001; Meunier et al., 2002) is yet unclear and is fully functional as a glycosyltransferase in vitro in the absence of other proteins.

Two UGGT family members are apparently catalytically inactive: one in human, hUGGT2, (Arnold et al., 2000) and one in S. cerevisiae, Kre5p (Meaden et al., 1990; Figure 2). In S. cerevisiae the loss of enzyme activity might be due to the lack of conservation of critical $D$ residues in the C-terminal catalytic domains of these enzymes (Tessier et al., 2000) (green boxes, shown with 4 in Figure 2). 
However, the conservation of these same motifs in the second catalytically inactive UGGT (hUGGT2) sequence suggests additional requirements for the enzyme activity. Comparisons of hUGGT1 and hUGGT2 protein sequences revealed differing residues in the catalytic domain (as identified by a blue $\star$ under the sequences in Figure 2); these residues may coincide with the loss of activity. Interestingly, three of these four residues also varied in the $S$. cerevisiae Kre5p sequence compared to all other homologues. Additionally, there is divergence within the $\mathrm{N}$-terminus region of hUGGT1 and hUGGT2 which may affect their substrate specificity (Arnold et al., 2000). As well, except first residue, all of these residues differ from all other homologues proteins with $S$. cerevisiae Kre5p sequence. Furthermore, we compared the known inactive UGGT sequences (hUGGT2 and Kre5p) to the known active UGGT sequences $(H$. sapiens UGGT $1, R$. norvegicus, $D$. melanogaster, and $S$. pombe UGGT proteins), revealing other candidate residues in the catalytic domain (as identified by a red $\star$ under the sequences in Figure 2).

Remarkably, the catalytically inactive $S$. cerevisiae gene is essential for cell viability (for a recent review, (Parodi, 2000) and appears to function early in the (1,6)- $\beta$-D-glucan synthesis pathway (Meaden et al., 1990). Higher eukaryotes (e.g. worms, rodents and humans) have evolved two UGGT genes with only one predicted to be catalytically active. An exciting possibility is that the catalytically inactive variants of UGGT including Kre5p are required for the disaggregation of misfolded proteins. At least four possible scenarios for these variants have also been proposed (Arnold et al., 2000) including different substrate specificity, a nucleotide sugar donor other than UDP-glucose, targeting a substrate for degradation, or binding of catalytically inactive hUGGT 2 to an unknown protein partner which would then elicit a gain of UGGT enzyme activity. Since, the enzymatically inactive EDEM (Hosokawa et al., 2001; Jakob et al., 2001a; Nakatsukasa et al., 2001) has been linked to quality control (Molinari et al., 2003; Oda et al., 2003) and ERp57 displays increased isomerase activity when associated with calnexin (Oliver et al., 1997; Zapun et al., 1998), this then raises the possibility of a role for the enzymatically "silent" UGGTs in quality control.

\section{Quality control implications for diseases}

Many human diseases can be classified as "protein trafficking diseases" where mutant secretory proteins are subjected to the ER quality control system and its associated ERAD (Amara et al., 1992; Aridor and Balch, 1999; Kim and Arvan, 1998; Kopito, 1999; Olkkonen and Ikonen, 2000; Thomas et al., 1995) (Table 1). These can be divided into three groups (I, II, and III, Table 1). The first group of diseases corresponds to loss of coupling to the ER export machinery leading to degradation of misfolded proteins. The second group of diseases correlates with ER accumulation of mutant proteins that are uncoupled from the ER export machinery and fail to be degraded and forms aggregates in the ER. The third group of diseases is due to defects in the machinery required for transport from the
ER to the Golgi complex (Aridor and Balch, 1999; Aridor and Hannan, 2000). In addition, viral and bacterial pathogens manipulate ER function for their immunological survival (Land and Braakman, 2001; Ploegh, 1998; Rust et al., 2001; Yamashita et al., 1996a) or to deliver their toxic products to the cytosol (Lord and Roberts, 1998). Viral infections are often linked to massive production of viral proteins and their accumulation in the ER (Aridor and Balch, 1999; Ploegh, 1998).

Mutant glycoproteins associated with protein trafficking diseases are also shown in Table 1 (Amara et al., 1992; Aridor and Balch, 1999; Kopito, 1999). The majorities of these proteins interact with calnexin and/or calreticulin and therefore are also potential substrates for UGGT. It is inferred that UGGT and its reglucosylation of mutant proteins is responsible for rebinding to CNX/CRT (for example, vesicular stomatitis virus $G$ (Peterson and Helenius, 1999), hemagglutinin (Peterson and Helenius, 1999), $\alpha_{1}$-antitrypsin (Choudhury, 1997), thyroglobulin (Parker et al., 1995) (Table 1), subunits of the T cell receptor (Gardner and Kearse, 1999).

From a therapeutic perspective, the problem of inherited protein misfolding is being addressed by several related strategies: One approach is based on attempts to chaperone misfolded proteins into a native-like structure that can evade the ER quality control machinery using either biological or chemical chaperones (Chow et al., 2001; Loo and Clarke, 1997). In another approach, to the accumulation of a mutant variant (PiZ) that is mostly retained in the ER (Qu et al., 1997) osmolytes such as trimethylamine- $\mathrm{N}$-oxide and sarcosine significantly reduce the rate of $\alpha_{1}$-antitrypsin mutant polymerization with no effect on the normal inhibitory function of $\alpha_{1}$-antitrypsin for serine proteases (Chow et al., 2001).

The other approach focuses on circumventing the quality control machinery of the ER, allowing proteins to be secreted, irrespective of their structural abnormalities (Burrows et al., 2000; Choo-Kang and Zeitlin, 2001; Rubenstein et al., 1997). The relevant example of this approach is the transmembrane conductance regulator protein (CFTR). The CFTR $\Delta$ F508 mutant is the most common cystic fibrosis allele and the mutated but otherwise functionally active protein is thus retained in the ER and eventually targeted for degradation, rather than being transported to the plasma membrane (Kopito and Ron, 2000; Kopito, 1999). The use of 4-phenylbutyrate (4PBA) increases the expression of the $\Delta F 508-C F T R$ mutant to the plasma membrane (Rubenstein et al., 1997), possibly acting through a cytosolic molecular chaperone, Hsp70 (Choo-Kang and Zeitlin, 2001). The use of specific mannosidase inhibitors may also been relevant to overcome the increased degradation and mislocation of mutant $\alpha_{1}$-antitrypsin (Marcus and Perlmutter, 2000).

Competitive or noncompetitive inhibition of UGGT, leading to inhibition of the CNX/CRT cycle, may be an alternative approach to development of therapies for protein misfolding diseases (see ref. Kopito and Ron, 2000). Although no specific inhibitors of this enzyme are known, related inhibitors may prove valuable to dissect a UGGT link to the diseases listed in Table 1 (Block and Jordan, 2001; Dwek et al., 2002). It is expected that mutation or 
removal of UGGT genes as well as components of the CNX/CRT cycle in mouse models of the diseases indicated in Table 1 will provide further insight into new targets.

\section{Acknowledgements}

We thank Pamela Cameron, Eric Chevet, Kurt Dejgaard, Ali Fazel, Annalyn Gilchrist, Michael Jain, and Hugues Nicolay for their kind help. Special thanks to Inci Ozer for her support. We apologize to colleagues whose original work we have not cited. Supported by grants to JJMB and DYT from the Canadian Institutes of Health Research.

\section{References}

Allen, S., A.C. Goodeve, I.R. Peake, and M.E. Daly. 2001. Endoplasmic reticulum retention and prolonged association of a von Willebrand's disease-causing von Willebrand factor variant with ERp57 and calnexin. Biochem. Biophys. Res Commun. 280:448-53.

Amara, J., S. Cheng, and A. Smith. 1992. Intracellular protein trafficking defects in human disease. Trends in Cell Biology. 2:145-149.

Amouzadeh, H., M. Bourdi, J. Martin, B. Martin, and L. Pohl. 1997. UDP-glucose:glycoprotein glucosyltransferase associates with endoplasmic reticulum chaperones and its activity is decreased in vivo by the inhalation anesthetic halothane. Chem. Res. Toxicol. 10:59-63.

Amselem, S., M. Sobrier, P. Duquesnoy, R. Rappaport, M. Postel-Vinay, M. Gourmelen, B. Dallapiccola, and M. Goossens. 1991. Recurrent nonsense mutations in the growth hormone receptor from patients with Laron dwarfism. J. Clin. Invest. 87:1098-102.

Aridor, M., and W. Balch. 1999. Integration of endoplasmic reticulum signaling in health and disease. Nat. Med. 5:745-51.

Aridor, M., and L.A. Hannan. 2000. Traffic jam: a compendium of human diseases that affect intracellular transport processes. Traffic. 1:836-51.

Aridor, M., and L.A. Hannan. 2002. Traffic jams II: an update of diseases of intracellular transport. Traffic. 3:781-90.

Arnold, S., L. Fessler, J. Fessler, and R. Kaufman. 2000. Two homologues encoding human UDPglucose:glycoprotein glucosyltransferase differ in mRNA expression and enzymatic activity. Biochemistry. 39:214963.

Bass, J., G. Chiu, Y. Argon, and D.F. Steiner. 1998. Folding of insulin receptor monomers is facilitated by the molecular chaperones calnexin and calreticulin and impaired by rapid dimerization. J. Cell Biol. 141:637-646.

Ben-Zeev, O., H.Z. Mao, and M.H. Doolittle. 2002. Maturation of lipoprotein lipase in the endoplasmic reticulum. Concurrent formation of functional dimers and inactive aggregates. J. Biol. Chem. 277:10727-10738.

Bergeron, J., M. Brenner, D. Thomas, and D. Williams. 1994. Calnexin: a membrane-bound chaperone of the endoplasmic reticulum. Trends Biochem. Sci. 19:124-8.

Block, T.M., and R. Jordan. 2001. Iminosugars as possible broad spectrum anti hepatitis virus agents: the glucovirs and alkovirs. Antivir. Chem. Chemother. 12:317-25.

Blond-Elguindi, S., A.M. Fourie, J.F. Sambrook, and M.J.
Gething. 1993. Peptide-dependent stimulation of the ATPase activity of the molecular chaperone BiP is the result of conversion of oligomers to active monomers. J. Biol. Chem. 268:12730-5.

Bolt, G. 2001. The measles virus (MV) glycoproteins interact with cellular chaperones in the endoplasmic reticulum and $\mathrm{MV}$ infection upregulates chaperone expression. Archives of Virology. 146: 2055-2068.

Bonen, D.K., F. Nassir, A.M.L. Hausman, and N.O. Davidson. 1998. Inhibition of N-linked glycosylation results in retention of intracellular apo[a] in hepatoma cells, although nonglycosylated and immature forms of apolipoprotein[a] are competent to associate with apolipoprotein B-100 in vitro. J. Lipid Res. 39:1629-1640.

Brada, D., and U.C. Dubach. 1984. Isolation of a homogeneous glucosidase II from pig kidney microsomes. Eur. J. Biochem. 141:149-56.

Braun, S., K. Matuschewski, M. Rape, S. Thoms, and S. Jentsch. 2002. Role of the ubiquitin-selective CDC48UFD1/NPL4 chaperone (segregase) in ERAD of OLE1 and other substrates. EMBO J. 21:615-621.

Breton, C., E. Bettler, D. Joziasse, R. Geremia, and A. Imberty. 1998. Sequence-function relationships of prokaryotic and eukaryotic galactosyltransferases. J. Biochem. 123:1000-9.

Burda, P., and M. Aebi. 1999. The dolichol pathway of Nlinked glycosylation. Biochim. Biophys. Acta. 1426:23957.

Burrows, J.A.J., L.K. Willis, and D.H. Perlmutter. 2000. Chemical chaperones mediate increased secretion of mutant alpha 1-antitrypsin (alpha 1-AT) Z: A potential pharmacological strategy for prevention of liver injury and emphysema in alpha 1-AT deficiency. PNAS. 97:17961801.

Cabral, C., Y. Liu, and R. Sifers. 2001. Dissecting glycoprotein quality control in the secretory pathway. Trends Biochem. Sci. 26:619-24.

Callea, F., M. Brisigotti, G. Fabbretti, F. Bonino, and V. Desmet. 1992. Hepatic endoplasmic reticulum storage diseases. Liver. 12:357-62.

Campbell, J., G. Davies, V. Bulone, and B. Henrissat. 1997. A classification of nucleotide-diphospho-sugar glycosyltransferases based on amino acid sequence similarities. Biochem. J. 326:929-39.

Cannon, K.S., D.N. Hebert, and A. Helenius. 1996. Glycandependent and -independent association of Vesicular Stomatitis Virus G protein with calnexin. J. Biol. Chem. 271:14280-14284.

Caramelo, J.J., O.A. Castro, L.G. Alonso, G. De Prat-Gay, and A.J. Parodi. 2003. UDP-Glc:glycoprotein glucosyltransferase recognizes structured and solvent accessible hydrophobic patches in molten globule-like folding intermediates. Proc. Natl. Acad. Sci. U SA. 100:8691.

Choo-Kang, L.R., and P.L. Zeitlin. 2001. Induction of HSP70 promotes \{Delta\}F508 CFTR Trafficking. Am. J. Physiol. Lung Cell Mol. Physiol. 281:L58-68.

Choudhury, P., Y. Liu, R.J. Bick, and R.N. Sifers. 1997. Intracellular association between UDPglucose:glycoprotein glucosyltransferase and an incompletely folded variant of alpha 1-antitrypsin. J. Biol. Chem. 272:13446-13451. 
Choukhi, A., S. Ung, C. Wychowski, and J. Dubuisson. 1998. Involvement of endoplasmic reticulum chaperones in the folding of hepatitis $\mathrm{C}$ virus glycoproteins. J. Virol. 72:3851-3858.

Chow, M., G. Devlin, and S. Bottomley. 2001. Osmolytes as modulators of conformational changes in serpins. Biol. Chem. 382:1593-9.

Coakley, R., C. Taggart, S. O'Neill, and N. McElvaney. 2001. Alpha1-antitrypsin deficiency: biological answers to clinical questions. Am. J. Med. Sci. 321:33-41.

Collins, S., C. McLean, and C. Masters. 2001. GerstmannStraussler-Scheinker syndrome,fatal familial insomnia, and kuru: a review of these less common human transmissible spongiform encephalopathies. J. Clin. Neurosci. 8:387-97.

de Carvalho, D.P., K.G. Rego, and D. Rosenthal. 1994. Thyroid peroxidase in dyshormonogenetic goiters with organification and thyroglobulin defects. Thyroid. 4:4216.

De Praeter, C.M., G.J. Gerwig, E. Bause, L.K. Nuytinck, J.F. Vliegenthart, W. Breuer, J.P. Kamerling, M.F. Espeel, J.J. Martin, A.M. De Paepe, N.W. Chan, G.A. Dacremont, and R.N. Van Coster. 2000. A novel disorder caused by defective biosynthesis of $\mathrm{N}$-linked oligosaccharides due to glucosidase I deficiency. Am. J. Hum. Genet. 66: 17441756.

Deutsch, C. 2002. Potassium channel ontogeny. Annu. Rev. Physiol. 64:19-46.

Doerrler, W.T., and M.A. Lehrman. 1999. Regulation of the dolichol pathway in human fibroblasts by the endoplasmic reticulum unfolded protein response. PNAS. 96:1305013055.

Drenth, J.P., R.H. te Morsche, R. Smink, J.S. Bonifacino, and J.B. Jansen. 2003. Germline mutations in PRKCSH are associated with autosomal dominant polycystic liver disease. Nat. Genet. 33: 345-347.

Dwek, R., T. Butters, F. Platt, and N. Zitzmann. 2002. Targeting glycosylation as a therapeutic approach. Nature Reviews Drug Discovery. 1:65-75.

Englender, T., A. Lattuada, P.M. Mannucci, J.E. Sadler, and A. Inbal. 1996. Analysis of Arg834GIn and Val902Glu type $2 \mathrm{~A}$ von Willebrand disease mutations: studies with recombinant von Willebrand factor and correlation with patient characteristics. Blood. 87:2788-94.

Fayadat, L., S. Siffroi-Fernandez, J. Lanet, and J.-L. Franc. 2000. Calnexin and calreticulin binding to human thyroperoxidase is required for its first folding step(s) but is not sufficient to promote efficient cell surface expression. Endocrinology. 141:959-966.

Fernandez, F., S. Trombetta, U. Hellman, and A. Parodi. 1994. Purification to homogeneity of UDP. glucose:glycoprotein glucosyltransferase from Schizosaccharomyces pombe and apparent absence of the enzyme from Saccharomyces cerevisiae. J. Biol. Chem. 269:30701-6.

Fewell, S.W., K.J. Travers, J.S. Weissman, and J.L. Brodsky. 2001. The action of molecular chaperones in the early secretory pathway. Annu. Rev. Genet. 35:149191.

Fiedler, K., M. Veit, M. Stamnes, and J. Rothman. 1996. Bimodal interaction of coatomer with the p24 family of putative cargo receptors. Science. 273:1396-9.
Frederick, J.M., N.V. Krasnoperova, K. Hoffmann, J. Church-Kopich, K. Ruther, K. Howes, J. Lem, and W. Baehr. 2001. Mutant rhodopsin transgene expression on a null background. Invest. Ophthalmol. Vis. Sci. 42: 826833.

Furutani, M., M.C. Trudeau, N. Hagiwara, A. Seki, Q. Gong, Z. Zhou, S. Imamura, H. Nagashima, H. Kasanuki, A. Takao, K. Momma, C.T. January, G.A. Robertson, and R. Matsuoka. 1999. Novel mechanism associated with an inherited cardiac arrhythmia: defective protein Trafficking by the mutant HERG (G601S) potassium channel. Circulation. 99:2290-4.

Gardner, T.G., and K.P. Kearse. 1999. Modification of the $\mathrm{T}$ cell antigen receptor (TCR) complex by UDP. glucose:glycoprotein glucosyltransferase. TCR folding is finalized convergent with formation of alpha beta delta epsilon gamma epsilon complexes. J. Biol. Chem. 274:14094-14099.

Garfield, N., and A. Karaplis. 2001. Genetics and animal models of hypoparathyroidism. Trends Endocrinol. Metab. 12:288-94.

Gedeon, A.K., A. Colley, R. Jamieson, E.M. Thompson, J. Rogers, D. Sillence, G.E. Tiller, J.C. Mulley, and J. Gecz. 1999. Identification of the gene (SEDL) causing X-linked spondyloepiphyseal dysplasia tarda. Nat. Genet. 22:4004.

Grinna, L.S., and P.W. Robbins. 1980. Substrate specificities of rat liver microsomal glucosidases which process glycoproteins. J. Biol. Chem. 255:2255-8.

Guerin, M. and A. J. Parodi. 2003. The UDPglucose:glycoprotein glucosyltransferase is organized in at least two tightly bound domains from yeast to mammals. J. Biol. Chem. 278: 20540-6.

Halaban, R., E. Cheng, Y. Zhang, G. Moellmann, D. Hanlon, M. Michalak, V. Setaluri, and D.N. Hebert. 1997. Aberrant retention of tyrosinase in the endoplasmic reticulum mediates accelerated degradation of the enzyme and contributes to the dedifferentiated phenotype of amelanotic melanoma cells. PNAS. 94:6210-6215.

Halaban, R., R.S. Patton, E. Cheng, S. Svedine, E.S. Trombetta, M.L. Wahl, S. Ariyan, and D.N. Hebert. 2002. Abnormal acidification of melanoma cells induces tyrosinase retention in the early secretory pathway. J. Biol. Chem. 277:14821-14828.

Hammond, C., I. Braakman, and A. Helenius. 1994. Role of $\mathrm{N}$-linked oligosaccharide recognition, glucose trimming, and calnexin in glycoprotein folding and quality control. PNAS. 91:913-917.

Hampton, R.Y. 2002. ER-associated degradation in protein quality control and cellular regulation. Curr. Opin. Cell Biol. 14:476-82.

Hebert, D., B. Foellmer, and A. Helenius. 1995. Glucose trimming and reglucosylation determine glycoprotein association with calnexin in the endoplasmic reticulum. Cell. 81:425-33.

Hebert, D., B. Foellmer, and A. Helenius. 1996. Calnexin and calreticulin promote folding, delay oligomerization and suppress degradation of influenza hemagglutinin in microsomes. EMBO J. 15:2961-8.

Helenius, A., E.S. Trombetta, D.N. Hebert, and J.F. Simons. 1997. Calnexin, calreticulin and the folding of glycoproteins. Trends in Cell Biology. 7:193-200. 
Hendershot, L.M. 2000. Giving protein traffic the green light. Nat. Cell Biol. 2:E105-6.

Hettkamp, H., G. Legler, and E. Bause. 1984. Purification by affinity chromatography of glucosidase I, an endoplasmic reticulum hydrolase involved in the processing of asparagine-linked oligosaccharides. Eur. J. Biochem. 142:85-90.

Hosokawa, N., I. Wada, K. Hasegawa, T. Yorihuzi, L. Tremblay, A. Herscovics, and K. Nagata. 2001. A novel ER alpha-mannosidase-like protein accelerates ERassociated degradation. EMBO Rep. 2:415-22.

Hsu, V., L. Yuan, J. Nuchtern, J. Lippincott-Schwartz, G. Hammerling, and R. Klausner. 1991. A recycling pathway between the endoplasmic reticulum and the Golgi apparatus for retention of unassembled MHC class I molecules. Nature. 352:441-4.

Illing, M.E., R.S. Rajan, N.F. Bence, and R.R. Kopito. 2002. A rhodopsin mutant linked to autosomal dominant retinitis pigmentosa is prone tp aggregate and interacts with the ubiquitin proteasome system. J. Biol. Chem. 277: 3415034160.

Ishii, S., Y. Suzuki, and J.Q. Fan. 2000. Role of Ser-65 in the activity of alpha-galactosidase A: characterization of a point mutation (S65T) detected in a patient with Fabry disease. Arch. Biochem. Biophys. 377:228-33.

Itin, C., R. Schindler, and H. Hauri. 1995. Targeting of protein ERGIC-53 to the ER/ERGIC/cis-Golgi recycling pathway. J Cell Biol. 131:57-67.

Jakob, C., D. Bodmer, U. Spirig, P. Battig, A. Marcil, D. Dignard, J. Bergeron, D. Thomas, and M. Aebi. 2001a. $\mathrm{Htm} 1 \mathrm{p}$, a mannosidase-like protein, is involved in glycoprotein degradation in yeast. EMBO Rep. 2:423-30. Jakob, C.A., E. Chevet, D.Y. Thomas, and J.J. Bergeron. 2001b. Lectins of the ER quality control machinery. Results Probl. Cell Differ. 33:1-17.

Jarosch, E., R. Geiss-Friedlander, B. Meusser, J. Walter, and T. Sommer. 2002. Protein dislocation from the endoplasmic reticulum-pulling out the suspect. Traffic. 3:530-6.

Jelinek-Kelly, S., and A. Herscovics. 1988. Glycoprotein biosynthesis in Saccharomyces cerevisiae. Purification of the alpha-mannosidase which removes one specific mannose residue from Man9GlcNAc. J. Biol. Chem. 263:14757-63.

Jorgensen, M.M., O.N. Jensen, H.U. Holst, J.-J. Hansen, T.J. Corydon, P. Bross, L. Bolund, and N. Gregersen. 2000. Grp78 Is Involved in Retention of Mutant Low Density Lipoprotein Receptor Protein in the Endoplasmic Reticulum. J. Biol. Chem. 275:33861-33868.

Kaback, M., and R. Desnick. 2001. Tay-Sachs disease: from clinical description to molecular defect. Adv. Genet. 44:1-9.

Kim, P., and P. Arvan. 1995. Calnexin and BiP act as sequential molecular chaperones during thyroglobulin folding in the endoplasmic reticulum. J. Cell Biol. 128:2938.

Kim, P.S., and P. Arvan. 1998. Endocrinopathies in the family of endoplasmic reticulum (ER) storage diseases: Disorders of protein trafficking and the role of ER molecular chaperones. Endocr. Rev. 19:173-202.

Kopito, R., and D. Ron. 2000. Conformational disease. Nat. Cell Biol. 2:E207-9.
Kopito, R.R. 1999. Biosynthesis and degradation of CFTR. Physiol. Rev. 79:167-173.

Kornfeld, R., and S. Kornfeld. 1985. Assembly of asparagine-linked oligosaccharides. Annu. Rev. Biochem. 54:631-64.

Korotkov, K.V., E. Kumaraswamy, Y. Zhou, D.L. Hatfield, and V.N. Gladyshev. 2001. Association between the 15kDa selenoprotein and UDP-glucose:glycoprotein glucosyltransferase in the endoplasmic reticulum of mammalian cells. J. Biol. Chem. 276:15330-15336.

Kuznetsov, G., L. B. Chen, et al. 1994. Several endoplasmic reticulum stress proteins, including ERp72, interact with thyroglobulin during its maturation. J. Biol. Chem. 269: 22990-5.

Kuznetsov, G., L. B. Chen, et al. 1997. Multiple molecular chaperones complex with misfolded large oligomeric glycoproteins in the endoplasmic reticulum. J. Biol. Chem. 272: 3057-63.

Kühn, L.C. 1999. Iron overload: molecular clues to its cause. Trends in Biochemical Sciences. 24:164-166.

Labriola, C., J.J. Cazzulo, and A.J. Parodi. 1999. Trypanosoma cruzi calreticulin is a lectin that binds monoglucosylated oligosaccharides but not protein moieties of glycoproteins. Mol. Biol. Cell. 10:1381-1394. Lamande, S., and J. Bateman. 1999. Procollagen folding and assembly: the role of endoplasmic reticulum enzymes and molecular chaperones. Semin Cell Dev. Biol. 10:45564.

Land, A., and I. Braakman. 2001. Folding of the human immunodeficiency virus type 1 envelope glycoprotein in the endoplasmic reticulum. Biochimie. 83:783-790.

Le, A., J. Steiner, G. Ferrell, J. Shaker, and R. Sifers. 1994. Association between calnexin and a secretionincompetent variant of human alpha 1-antitrypsin.: J. Biol. Chem. 269:7514-9.

Lodish, H.F., N. Kong, M. Snider, and G.J. Strous. 1983. Hepatoma secretory proteins migrate from rough endoplasmic reticulum to Golgi at characteristic rates. Nature. 304:80-3.

Loo, T.W., and D.M. Clarke. 1997. Identification of residues in the drug-binding site of human P-glycoprotein using a thiol-reactive substrate. J. Biol. Chem. 272:31945-31948.

Lord, J.M., and Roberts, LM. 1998. Toxin Entry: Retrograde Transport through the secretory pathway. J. Cell Biol. 140:733-736.

Lyons, S.E., M.E. Bruck, E.J. Bowie, and D. Ginsburg. 1992. Impaired intracellular transport produced by a subset of type IIA von Willebrand disease mutations. J. Biol. Chem. 267:4424-30.

Marcus, N.Y., and D.H. Perlmutter. 2000. Glucosidase and mannosidase inhibitors mediate increased secretion of mutant alpha 1 antitrypsin Z. J. Biol. Chem. 275:19871992.

McGinnes, L.W., and T.G. Morrison. 1998. Role of carbohydrate processing and calnexin binding in the folding and activity of the HN protein of Newcastle disease virus. Virus Research. 53:175-185.

Meacham, G.C., C. Patterson, W. Zhang, J.M. Younger, and D.M. Cyr. 2001. The Hsc70 co-chaperone CHIP targets immature CFTR for proteasomal degradation. Nat. Cell Biol. 3:100-5. 
Meaden, P., K. Hill, J. Wagner, D. Slipetz, S. Sommer, and H. Bussey. 1990. The yeast KRE5 gene encodes a probable endoplasmic reticulum protein required for (16)-beta-D-glucan synthesis and normal cell growth. Mol. Cell Biol. 10:3013-9.

Mendell, J. 1998. Charcot-Marie-Tooth neuropathies and related disorders. Semin. Neurol. 18:41-7.

Meunier, L., Y.K. Usherwood, K.T. Chung, and L.M. Hendershot. 2002. A subset of chaperones and folding enzymes form multiprotein complexes in endoplasmic reticulum to bind nascent proteins. Mol. Biol. Cell. 13:4456-69.

Mezzacasa, A., and A. Helenius. 2002. The transitional ER defines a boundary for quality control in the secretion of tsO45 VSV glycoprotein. Traffic. 3:833-49.

Michalak, M., E. Corbett, N. Mesaeli, K. Nakamura, and M. Opas. 1999. Calreticulin: one protein, one gene, many functions. Biochem. J. 344:281-92.

Miura, Y., F. Kambe, I. Yamamori, Y. Mori, Y. Tani, Y. Murata, Y. Oiso, and H. Seo. 1994. A truncated thyroxine-binding globulin due to a frameshift mutation is retained within the rough endoplasmic reticulum: a possible mechanism of complete thyroxine-binding globulin deficiency in Japanese. J. Clin. Endocrinol. Metab. 78:283-7.

Molinari, M. and A. Helenius. 1999. Glycoproteins form mixed disulphides with oxidoreductases during folding in living cells. Nature 402: 90-3.

Molinari, M., V. Calanca, C. Galli, P. Lucca, and P. Paganetti. 2003. Role of EDEM in the release of misfolded glycoproteins from the calnexin cycle. Science. 299:1397400.

Molinari, M., C. Galli, V. Piccaluga, M. Pieren, and P. Paganetti. 2002. Sequential assistance of molecular chaperones and transient formation of covalent complexes during protein degradation from the ER. J. Cell Biol. 158:247-57.

Molinari, M., and A. Helenius. 2000. Chaperone selection during glycoprotein translocation into the endoplasmic reticulum. Science. 288:331-333.

Morello, J., A. Salahpour, U. Petaja-Repo, A. Laperriere, M. Lonergan, M. Arthus, I. Nabi, D. Bichet, and M. Bouvier. 2001. Association of calnexin with wild type and mutant AVPR2 that causes nephrogenic diabetes insipidus. Biochemistry. 40:6766-75.

Naim, H., J. Roth, E. Sterchi, M. Lentze, P. Milla, J. Schmitz, and $\mathrm{H}$. Hauri. 1988. Sucrase-isomaltase deficiency in humans. Different mutations disrupt intracellular transport, processing, and function of an intestinal brush border enzyme. J. Clin. Invest. 82:667-79.

Nakatsukasa, K., S.-i. Nishikawa, N. Hosokawa, K. Nagata, and T. Endo. 2001. Mnl1p, an alpha -mannosidase-like protein in yeast Saccharomyces cerevisiae, is required for Endoplasmic reticulum-associated degradation of glycoproteins. J. Biol. Chem. 276:8635-8638.

Nakhasi, H., M. Ramanujam, C. Atreya, T. Hobman, N. Lee, A. Esmaili, and R. Duncan. 2001. Rubella virus glycoprotein interaction with the endoplasmic reticulum calreticulin and calnexin. Arch Virol. 146:1-14.

Nauseef, W. 1999. Quality control in the endoplasmic reticulum: lessons from hereditary myeloperoxidase deficiency. J. Lab. Clin. Med. 134:215-21.
Nauseef, W.M., S.J. McCormick, and M. Goedken. 1998. Coordinated participation of calreticulin and calnexin in the biosynthesis of myeloperoxidase. J. Biol. Chem. 273:7107-7111.

Nichols, W., U. Seligsohn, A. Zivelin, V. Terry, C. Hertel, M. Wheatley, M. Moussalli, H. Hauri, N. Ciavarella, R. Kaufman, and D. Ginsburg. 1998. Mutations in the ERGolgi intermediate compartment protein ERGIC-53 cause combined deficiency of coagulation factors $\mathrm{V}$ and VIII. Cell. 93:61-70.

Nilsson, T., M. Jackson, and P. Peterson. 1989. Short cytoplasmic sequences serve as retention signals for transmembrane proteins in the endoplasmic reticulum. Cell. 58:707-18.

Oda, Y., N. Hosokawa, I. Wada, and K. Nagata. 2003. EDEM as an acceptor of terminally misfolded glycoproteins released from calnexin. Science. 299:13947.

Oliver, J.D., F.J. van der Wal, N.J. Bulleid, and S. High. 1997. Interaction of the thiol-dependent reductase ERp57 with nascent glycoproteins. Science. 275:86-88.

Olkkonen, V., and E. Ikonen. 2000. Genetic defects of intracellular-membrane transport. New Engl. J. Med. 343:1095-104.

Ou, W., P. Cameron, D. Thomas, and J. Bergeron. 1993. Association of folding intermediates of glycoproteins with calnexin during protein maturation. Nature. 364:771-6.

Parker, C.G., L.I. Fessler, R.E. Nelson, and J.H. Fessler. 1995. Drosophila UDP-glucose:glycoprotein glucosyltransferase: sequence and characterization of an enzyme that distinguishes between denatured and native proteins. EMBO J. 14:1294-303.

Parodi, A., and J. Cazzulo. 1982. Protein glycosylation in Trypanosoma cruzi. II. Partial characterization of proteinbound oligosaccharides labeled "in vivo". J. Biol. Chem. 257:7641-5.

Parodi, A.J. 2000. Protein glucosylation and its role in protein folding. Annu. Rev. Biochem. 69:69-93.

Pelham, H. 1996. The dynamic organisation of the secretory pathway. Cell Struct. Funct. 21:413-9.

Pelletier, M.F., A. Marcil, G. Sevigny, C.A. Jakob, D.C. Tessier, E. Chevet, R. Menard, J.J. Bergeron, and D.Y. Thomas. 2000. The heterodimeric structure of glucosidase II is required for its activity, solubility, and localization in vivo. Glycobiology. 10:815-27.

Peterson, J., and A. Helenius. 1999. In vitro reconstitution of calreticulin-substrate interactions. J. Cell Sci. 112:27752784.

Pilon, M., R. Schekman, and K. Romisch. 1997. Sec61p mediates export of a misfolded secretory protein from the endoplasmic reticulum to the cytosol for degradation. EMBO J. 16:4540-4548.

Pind, S., J. Riordan, and D. Williams. 1994. Participation of the endoplasmic reticulum chaperone calnexin (p88, IP90) in the biogenesis of the cystic fibrosis transmembrane conductance regulator. J. Biol. Chem. 269:12784-8.

Ploegh, H.L. 1998. Viral strategies of immune evasion. Science. 280:248-253.

Prange, R., M. Werr, and H. Loffler-Mary. 1999. Chaperones involved in hepatitis B virus morphogenesis. Biol. Chem. 380:305-14. 
Qu, D., J. Teckman, and D. Perlmutter. 1997. Review: alpha 1-antitrypsin deficiency associated liver disease. J. Gastroenterol. Hepatol. 12:404-16.

Qu, D., J. H. Teckman, et al. 1996. Degradation of a Mutant Secretory Protein, alpha 1-Antitrypsin Z, in the Endoplasmic Reticulum Requires Proteasome Activity. J. Biol. Chem. 271(37): 22791-22795.

Refetoff, S., Y. Murata, Y. Mori, O.E. Janssen, K. Takeda, and Y. Hayashi. 1996. Thyroxine-binding globulin: organization of the gene and variants. Horm. Res. 45:12838.

Reznik, S., and L. Fricker. 2001. Carboxypeptidases from A to Z: implications in embryonic development and Wnt binding. Cell Mol. Life Sci. 58:1790-804.

Ritter, C., and A. Helenius. 2000. Recognition of local glycoprotein misfolding by the ER folding sensor UDPglucose:glycoprotein glucosyltransferase. Nat. Struct. Biol. 7:278-80.

Rodan, A.R., J.F. Simons, E.S. Trombetta, and A. Helenius. 1996. N-linked oligosaccharides are necessary and sufficient for association of glycosylated forms of bovine RNase with calnexin and calreticulin. EMBO J. 15:692130.

Roth, J., C. Zuber, B. Guhl, J. Fan, and M. Ziak. 2002. The importance of trimming reactions on asparagine-linked oligosaccharides for protein quality control. Histochem. Cell Biol. 117:159-69.

Roy, S., A. Sun, and C. Redman. 1996. In vitro assembly of the component chains of fibrinogen requires endoplasmic reticulum factors. J. Biol. Chem. 271:2454424550.

Rubenstein, R.C., M.E. Egan, and P.L. Zeitlin. 1997. In vitro pharmacologic restoration of CFTR-mediated chloride transport with sodium 4-phenylbutyrate in cystic fibrosis epithelial cells containing delta F508-CFTR. J. Clin. Invest. 100:2457-2465.

Rudd, P., G. Opdenakker, and R. Dwek. 2001a. Holistic approaches to glycobiology. Nat. Biotechnol. 19:531-2.

Rudd, P., M. Wormald, D. Wing, S. Prusiner, and R. Dwek. 2001b. Prion glycoprotein: structure, dynamics, and roles for the sugars. Biochemistry. 40:3759-66.

Rudd, P.M., T. Elliott, P. Cresswell, I.A. Wilson, and R.A. Dwek. 2001c. Glycosylation and the immune system. Science. 291:2370-2376.

Rust, R.C., L. Landmann, R. Gosert, B.L. Tang, W. Hong, H.-P. Hauri, D. Egger, and K. Bienz. 2001. Cellular COPII proteins are involved in production of the vesicles that form the poliovirus replication complex. J. Virol. 75:98089818.

Saliba, R.S., P.M.G. Munro, P.J. Luthert, and M.E. Cheetham. 2002. The cellular fate of mutant rhodopsin: quality control, degradation and aggresome formation. J. Cell Sci. 115: 2907-2918.

Sampietro, M., and A. Iolascon. 1999. Molecular pathology of Crigler-Najjar type I and II and Gilbert's syndromes. Haematologica. 84:150-7.

Schrag, J.D., B. J.J., Y. Li, S. Borisova, M. Hahn, D.Y. Thomas, and M. Cygler. 2001. The Structure of calnexin, an ER chaperone involved in quality control of protein folding. Mol. Cell. 8:633-44.

Shastry, B. 2001. Molecular and cell biological aspects of Alzheimer disease. J. Hum. Genet. 46:609-18.
Silberstein, S., and R. Gilmore. 1996. Biochemistry, molecular biology, and genetics of the oligosaccharyltransferase. FASEB J. 10:849-58.

Sousa, M., M. Ferrero-Garcia, and A. Parodi. 1992. Recognition of the oligosaccharide and protein moieties of glycoproteins by the UDP-Glc:glycoprotein glucosyltransferase. Biochemistry. 31:97-105.

Sousa, M., and A. Parodi. 1995. The molecular basis for the recognition of misfolded glycoproteins by the UDPGlc:glycoprotein glucosyltransferase. EMBO J. 14:4196203.

Spiro, R.G., Q. Zhu, V. Bhoyroo, and H.-D. Söling. 1996. Definition of the lectin-like properties of the molecular chaperone, calreticulin, and demonstration of its copurification with endomannosidase from rat liver Golgi. J. Biol. Chem. 271:11588-11594.

Suh, K., J.E. Bergmann, and C.A. Gabel. 1989. Selective retention of monoglucosylated high mannose oligosaccharides by a class of mutant vesicular stomatitis virus G proteins. J. Cell Biol. 108:811-9.

Swanton, E., S. High, and P. Woodman. 2003. Role of calnexin in the glycan-independent quality control of proteolipid protein. EMBO J. 22: 2948-2958.

Tamarappoo, B.K., B. Yang, and A.S. Verkman. 1999. Misfolding of mutant aquaporin-2 water channels in nephrogenic Diabetes Insipidus. J. Biol. Chem. 274:34825-34831.

Tatu, U. and A. Helenius 1997. Interactions between newly synthesized glycoproteins, calnexin and a network of resident chaperones in the endoplasmic reticulum. J. Cell Biol. 136: 555-65.

Taylor, S.C., P. Thibault, D.C. Tessier, J.J. Bergeron, and D.Y. Thomas. 2003. Glycopeptide specificity of the secretory protein folding sensor UDP-glucose glycoprotein:glucosyltransferase. EMBO Rep. 4:405-11. Tessier, D., D. Dignard, A. Zapun, A. Radominska-Pandya, A. Parodi, J. Bergeron, and D. Thomas. 2000. Cloning and characterization of mammalian UDP-glucose glycoprotein: glucosyltransferase and the development of a specific substrate for this enzyme. Glycobiology. 10:403-12.

Thomas, P.J., B.-H. Qu, and P.L. Pedersen. 1995. Defective protein folding as a basis of human disease. Trends in Biochemical Sciences. 20:456-459.

Thomas, P.K. 1999. Overview of Charcot-Marie-Tooth disease type 1A. Ann. NY Acad. Sci. 883:1-5.

Tokunaga, F., C. Brostrom, T. Koide, and P. Arvan. 2000. Endoplasmic reticulum (ER)-associated degradation of misfolded N-linked glycoproteins is suppressed upon inhibition of ER mannosidase I. J. Biol. Chem. 275:4075740764.

Trombetta, E.S., and A. Helenius. 1999. Glycoprotein reglucosylation and nucleotide sugar utilization in the secretory pathway: identification of a nucleoside diphosphatase in the endoplasmic reticulum. EMBO J. 18:3282-3292.

Trombetta, E.S., and A. Helenius. 2000. Conformational requirements for glycoprotein reglucosylation in the endoplasmic reticulum. J. Cell Biol. 148:1123-1130.

Trombetta, E.S., J.F. Simons, and A. Helenius. 1996. Endoplasmic reticulum glucosidase II is composed of a 
catalytic subunit, conserved from yeast to mammals, and a tightly bound noncatalytic HDEL-containing subunit. J. Biol. Chem. 271:27509-27516.

Trombetta, S., M. Bosch, and A. Parodi. 1989. Glucosylation of glycoproteins by mammalian, plant, fungal, and trypanosomatid protozoa microsomal membranes. Biochemistry. 28:8108-16.

Trombetta, S., and A. Parodi. 1992. Purification to apparent homogeneity and partial characterization of rat liver UDPglucose:glycoprotein glucosyltransferase. J. Biol. Chem. 267:9236-40.

Van Leeuwen, J.E.M., and K.P. Kearse. 1997. Reglucosylation of $\mathrm{N}$-linked glycans is critical for calnexin assembly with $\mathrm{T}$ cell receptor (TCR) alpha proteins but not TCRbeta proteins. J. Biol. Chem. 272:4179-4186.

Vashist, S., W. Kim, W.J. Belden, E.D. Spear, C. Barlowe, and D.T.W. Ng. 2001. Distinct retrieval and retention mechanisms are required for the quality control of endoplasmic reticulum protein folding. J. Cell Biol. 155:355-368.

Veijola, J., and R.F. Pettersson. 1999. Transient association of calnexin and calreticulin with newly synthesized G1 and $\mathrm{G} 2$ glycoproteins of uukuniemi virus (family Bunyaviridae). J. Virol. 73:6123-6127.

Verpy, E., E. Couture-Tosi, and T. M. 1993. C1 inhibitor mutations which affect intracellular transport and secretion in type I hereditary angioedema. Behring Inst Mitt. 93:1204.

Vinayagamoorthy, T., and A. Rajakumar. 1996. Stress relief protein modulation by calnexin. Ann. NY Acad. Sci. 793:479-84.

Wada, I., M. Kai, S. Imai, F. Sakane, and H. Kanoh. 1997. Promotion of transferrin folding by cyclic interactions with calnexin and calreticulin. EMBO J. 16:5420-5432.

Weng, S., and R. Spiro. 1993. Demonstration that a kifunensine-resistant alpha-mannosidase with a unique processing action on $\mathrm{N}$-linked oligosaccharides occurs in rat liver endoplasmic reticulum and various cultured cells. J. Biol. Chem. 268:25656-63.

White, A.L., B. Guerra, J. Wang, and R.E. Lanford. 1999. Presecretory degradation of apolipoprotein[a] is mediated by the proteasome pathway. J. Lipid Res. 40:275-286.

Wiertz, E., D. Tortorella, M. Bogyo, J. Yu, W. Mothes, T. Jones, T. Rapoport, and H. Ploegh. 1996. Sec61mediated transfer of a membrane protein from the endoplasmic reticulum to the proteasome for destruction. Nature. 384:432-8.

Wu, S., C. Lee, C. Liao, R. Dwek, N. Zitzmann, and Y. Lin. 2002. Antiviral effects of an iminosugar derivative on flavivirus infections. J. Virol. 76:3596-604.

Yamamoto, K., R. Fujii, Y. Toyofuku, T. Saito, H. Koseki, V.W. Hsu, and T. Aoe. 2001. The KDEL receptor mediates a retrieval mechanism that contributes to quality control at the endoplasmic reticulum. EMBO J. 20:3082-3091.

Yamashita, Y., K. Shimokata, S. Mizuno, T. Daikoku, T. Tsurumi, and Y. Nishiyama. 1996a. Calnexin acts as a molecular chaperone during the folding of glycoprotein B of human cytomegalovirus. J. Virol. 70:2237-2246.

Yamashita, Y., M. Yamada, T. Daikoku, H. Yamada, A. Tadauchi, T. Tsurumi, and Y. Nishiyama. 1996b. Calnexin associates with the precursors of glycoproteins $B, C$, and $D$ of herpes simplex virus type 1. Virology. 225:216-22.

Ye, Y., H. Meyer, and T. Rapoport. 2001. The AAA ATPase Cdc48/p97 and its partners transport proteins from the ER into the cytosol. Nature. 414:652-6.

Yool, D., J. Edgar, P. Montague, and S. Malcolm. 2000. The proteolipid protein gene and myelin disorders in man and animal models. Hum. Mol. Genet. 9:987-92.

Yoshida, H., T. Matsui, N. Hosokawa, R.J. Kaufman, K. Nagata, and K. Mori. 2003. A time-dependent phase shift in the mammalian unfolded protein response. Dev. Cell. 4:265-71.

Yoshida, Y., T. Chiba, F. Tokunaga, H. Kawasaki, K. Iwai, T. Suzuki, Y. Ito, K. Matsuoka, M. Yoshida, K. Tanaka, and T. Tai. 2002. E3 ubiquitin ligase that recognizes sugar chains. Nature. 418:438-42.

Zapun, A., N.J. Darby, D.C. Tessier, M. Michalak, J.J.M. Bergeron, and D.Y. Thomas. 1998. Enhanced catalysis of Ribonuclease $B$ folding by the interaction of calnexin or calreticulin with ERp57. J. Biol. Chem. 273:6009-6012.

Zapun, A., C. Jakob, D. Thomas, and J. Bergeron. 1999. Protein folding in a specialized compartment: the endoplasmic reticulum. Structure Fold. Des. 7:R173-82.

Zapun, A., S. Petrescu, P. Rudd, R. Dwek, D. Thomas, and J. Bergeron. 1997. Conformation-independent binding of monoglucosylated ribonuclease $B$ to calnexin. Cell. 88:29-38.

Zuber, C., J.-y. Fan, B. Guhl, A. Parodi, J.H. Fessler, C. Parker, and J. Roth. 2001. Immunolocalization of UDPglucose:glycoprotein glucosyltransferase indicates involvement of pre-Golgi intermediates in protein quality control. PNAS. 98:10710-10715.

Zuber, C., M.J. Spiro, B. Guhl, R.G. Spiro, and J. Roth. 2000. Golgi apparatus. Immunolocalization of endomannosidase suggests post-endoplasmic reticulum glucose trimming: Implications for quality control. Mol. Biol. Cell. 11:4227-4240. 


\section{Further Reading}

Caister Academic Press is a leading academic publisher of advanced texts in microbiology, molecular biology and medical research. Full details of all our publications at caister.com

- MALDI-TOF Mass Spectrometry in Microbiology Edited by: M Kostrzewa, S Schubert (2016) www.caister.com/malditof

- Aspergillus and Penicillium in the Post-genomic Era Edited by: RP Vries, IB Gelber, MR Andersen (2016) www.caister.com/aspergillus2

- The Bacteriocins: Current Knowledge and Future Prospects Edited by: RL Dorit, SM Roy, MA Riley (2016)

www.caister.com/bacteriocins

- Omics in Plant Disease Resistance Edited by: V Bhadauria (2016) www.caister.com/opd

- Acidophiles: Life in Extremely Acidic Environments Edited by: R Quatrini, DB Johnson (2016) www.caister.com/acidophiles

- Climate Change and Microbial Ecology: Current Research and Future Trend

Edited by: J Marxsen (2016)

www.caister.com/climate

- Biofilms in Bioremediation: Current Research and Emerging Technologies

Edited by: G Lear (2016)

www.caister.com/biorem

- Microalgae: Current Research and Applications Edited by: MN Tsaloglou (2016) www.caister.com/microalgae

- Gas Plasma Sterilization in Microbiology: Theory, Applications, Pitfalls and New Perspectives Edited by: H Shintani, A Sakudo (2016) www.caister.com/gasplasma

- Virus Evolution: Current Research and Future Directions Edited by: SC Weaver, M Denison, M Roossinck, et al. (2016) www.caister.com/virusevol

- Arboviruses: Molecular Biology, Evolution and Control Edited by: N Vasilakis, DJ Gubler (2016) www.caister.com/arbo

- Shigella: Molecular and Cellular Biology Edited by: WD Picking, WL Picking (2016) www.caister.com/shigella

-Aquatic Biofilms: Ecology, Water Quality and Wastewater Treatment

Edited by: AM Romaní, H Guasch, MD Balaguer (2016)

www.caister.com/aquaticbiofilms

- Alphaviruses: Current Biology

Edited by: S Mahalingam, L Herrero, B Herring (2016)

www.caister.com/alpha

- Thermophilic Microorganisms

Edited by: F Li (2015)

www.caister.com/thermophile
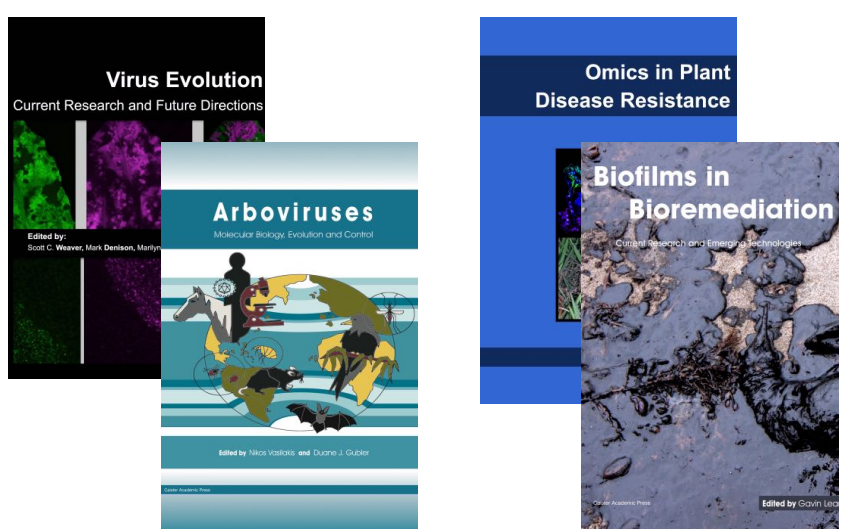
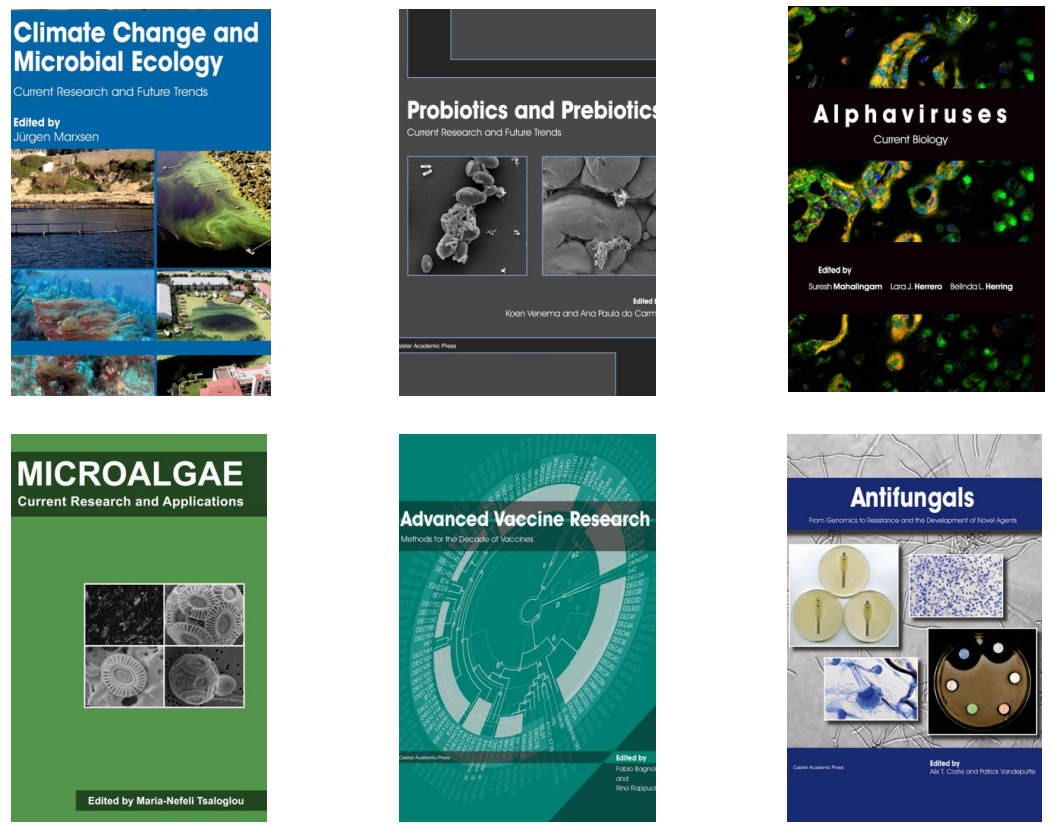

- Flow Cytometry in Microbiology: Technology and Applications Edited by: MG Wilkinson (2015) www.caister.com/flow

- Probiotics and Prebiotics: Current Research and Future Trends Edited by: K Venema, AP Carmo (2015) www.caister.com/probiotics

- Epigenetics: Current Research and Emerging Trends Edited by: BP Chadwick (2015) www.caister.com/epigenetics2015

- Corynebacterium glutamicum: From Systems Biology to Biotechnological Applications

Edited by: A Burkovski (2015)

www.caister.com/cory2

- Advanced Vaccine Research Methods for the Decade of Vaccines

Edited by: F Bagnoli, R Rappuoli (2015)

www.caister.com/vaccines

- Antifungals: From Genomics to Resistance and the Development of Novel Agents

Edited by: AT Coste, P Vandeputte (2015)

www.caister.com/antifungals

- Bacteria-Plant Interactions: Advanced Research and Future Trends Edited by: J Murillo, BA Vinatzer, RW Jackson, et al. (2015) www.caister.com/bacteria-plant

\section{- Aeromonas}

Edited by: J Graf (2015)

www.caister.com/aeromonas

- Antibiotics: Current Innovations and Future Trends

Edited by: S Sánchez, AL Demain (2015)

www.caister.com/antibiotics

- Leishmania: Current Biology and Contro Edited by: S Adak, R Datta (2015) www.caister.com/leish2

- Acanthamoeba: Biology and Pathogenesis (2nd edition) Author: NA Khan (2015)

www.caister.com/acanthamoeba2

- Microarrays: Current Technology, Innovations and Applications Edited by: Z He (2014)

www.caister.com/microarrays2

- Metagenomics of the Microbial Nitrogen Cycle: Theory, Methods and Applications

Edited by: D Marco (2014)

www.caister.com/n2 